\title{
Second-line Treatment in Advanced Biliary Tract Cancer: Today and Tomorrow
}

\author{
ALESSANDRO RIZZO*, ANGELA DALIA RICCI*, NASTASSJA TOBER, MARIA CONCETTA NIGRO, \\ MIRTA MOSCA, ANDREA PALLONI, FRANCESCA ABBATI, GIORGIO FREGA, \\ STEFANIA DE LORENZO, SIMONA TAVOLARI and GIOVANNI BRANDI \\ Department of Experimental, Diagnostic and Specialty Medicine, \\ S. Orsola-Malpighi University Hospital, Bologna, Italy
}

\begin{abstract}
Biliary tract cancer (BTC) patients usually have poor prognosis. Whereas combination chemotherapy has been shown to improve survival in the frontline setting, second-line treatment is subject to a lot of debate in the scientific community. Recent data of the ABC-06 trial has provided slight evidence for the use of second-line chemotherapy after progression on cisplatin plus gemcitabine combination. In this study, mFOLFOX plus active symptom control (ASC) improved overall survival (OS) after progression on cisplatingemcitabine combination compared with ASC alone, with an increase in 6- and 12-month OS rate. Although genomic studies have paved the way for a new age in cancer management, the "Precision Medicine Era" in BTC is still limited to intrahepatic cholangiocarcinoma and primarily focused on isocitrate dehydrogenase (IDH) and fibroblast growth factor receptor (FGFR) targeted therapies. We herein review recent published data regarding the use of second-line treatment after failure of standard first-line therapies in BTC patients, with a particular focus on ongoing active and recruiting clinical trials.
\end{abstract}

Biliary tract cancer (BTC) accounts for $3 \%$ of all gastrointestinal malignancies and represents the second most common primary liver cancer, following hepatocellular

This article is freely accessible online.

*These Authors contributed equally to this study.

Correspondence to: Rizzo Alessandro, Department of Experimental, Diagnostic and Specialty Medicine, S. Orsola-Malpighi University Hospital, Bologna, Italy. Tel: +39 0512144078, Fax: +39 0516364037, e-mail: Rizzo.alessandro179@gmail.com

Key Words: Biliary tract cancer, cholangiocarcinoma, targeted therapy, chemotherapy, second-line, review. carcinoma (HCC) $(1,2)$. BTC comprises a spectrum of malignancies usually classified into intrahepatic cholangiocarcinoma (iCCA), extrahepatic cholangiocarcinoma (eCCA), gallbladder cancer (GBC) and ampulla of Vater cancer (AVC) $(3,4)$. The term cholangiocarcinoma (CCA) historically embraces iCCA and eCCA, therefore excluding AVC and GBC (5). The incidence of BTC has increased over the past two decades, mainly due to the increase in iCCA in both western and eastern countries and as a result of better disease recognition $(6,7)$. Despite recent improvements in the field of medical oncology, the prognosis of BTC patients remains dismal since the majority of cases are diagnosed with inoperable disease and, even after radical surgery, the 5-year overall survival (OS) rate is approximately $15 \%(8,9)$.

In the advanced disease setting, first-line systemic chemotherapy is considered the backbone of treatment, following the results of the $\mathrm{ABC}-02$ trial where the cisplatin plus gemcitabine (CisGem) combination was shown to improve OS over gemcitabine alone in 410 patients with locally advanced or metastatic BTC [11.7 versus 8.1 months; hazard ratio $(\mathrm{HR}) 0.64 ; 95 \% \mathrm{CI}=0.52-0.80 ; p<0.001](10)$; moreover, this randomized phase III trial reported improved progression-free survival (PFS) for the combination treatment over single-agent gemcitabine (8.0 months versus 5.0 months, $p<0.001)$. Although the landmark study by Valle et al. certainly represented a historical step forward in the palliative treatment of BTC, the survival advantage of frontline therapy is modest, with nearly all patients developing progressive disease following first-line chemotherapy (11, 12). Nevertheless, some patients still maintain a good general condition after failing first-line therapies, with around 30$35 \%$ continuing on second-line treatment, according to previous studies $(13,14)$. Thus, this subgroup of patients has another chance to control the malignancy, aiming at maintaining an acceptable quality of life and even improving survival. 
The advent of genomic sequencing has led to a better comprehension of the complex molecular mechanisms underlying the pathogenesis of BTC (Figure 1) (15). In fact, several driver genetic alterations have been identified, including fibroblast growth factor receptor $(F G F R)$ fusions, isocitrate dehydrogenase $(I D H)$ mutations and many others, and targeted therapies are emerging as new promising treatment modalities for BTC $(16,17)$. Interestingly enough, recent molecular profiling studies have detected that at least $40 \%$ of BTC patients present potentially targetable alterations, with relevant differences between different anatomical subgroups (18).

The era of modern cancer care has also been characterized by the introduction of immunotherapy, which has revolutionized the treatment landscape of several hematological and solid tumors (19-21). Although immune checkpoint inhibitors (ICIs) have become the standard treatment of malignancies such as advanced melanoma and non-small cell lung cancer (NSCLC) $(22,23)$, immunotherapy for BTC is still in the early phases and, as we shall see later, several ongoing trials are investigating the role of ICI monotherapy or combination chemo-immunotherapy in untreated and previously treated patients.

The current review provides an update on the available evidence regarding second-line treatment in locally advanced or metastatic BTC, with a particular focus on recent published data and chief ongoing active and recruiting trials.

\section{Cytotoxic Therapy}

While first-line systemic chemotherapy is a generally recognized treatment strategy for improving survival and quality-of-life in advanced BTC (10-12), until the past year, there was no consensus regarding the benefit of second-line systemic chemotherapy. Results concerning the efficacy and safety of second-line treatment in advanced BTC have come previously from retrospective studies with small sample size (24). Second-line fluoropyrimidine monotherapy revealed limited efficacy with a median PFS of 2.5-5.5 months and a median OS of 7.5-13.5 months, respectively (25-27), whereas fluoropyrimidine-based combination therapy with either oxaliplatin (FOLFOX) or irinotecan (FOLFIRI) showed a median PFS of 1.6-3.9 months and a median OS of 4.4-8.4 months (28-31).

In the last few years, two papers have summarized the results of studies assessing the efficacy of second-line chemotherapy in BTC $(32,33)$.

First, Lamarca et al. in 2014 performed a systematic review to evaluate the level of evidence for the use of secondline therapy in 761 BTC patients (32). This systematic review reported a mean OS of 7.2 months $(95 \% \mathrm{CI}=6.2-8.2)$ in patients receiving second-line treatment while mean PFS, response rate $(\mathrm{RR})$ and disease control rate (DCR) were 3.2 months $(95 \% \mathrm{CI}=2.7-3.7), 7.7 \%(95 \% \mathrm{CI}=4.6-10.9)$ and $49.5 \%$ (95\% CI=41.4-57.7), respectively.

In 2019, a meta-analysis by Ying et al. evaluated the role of second-line treatment for advanced BTC in terms of response, OS and toxicities, collecting data from 32 published studies including 1391 patients (33). The weighted median PFS and OS for refractory BTCs which received second-line therapy were 2.6 months and 6.5 months, respectively, and combined second-line treatment was not superior to monotherapy in terms of objective response rate (ORR) (33).

Results from the ABC-06, open-label, randomized, multicenter trial comparing 12 cycles of mFOLFOX plus active symptom control (ASC) with ASC alone in the second line setting, were presented at the ASCO 2019 Annual Meeting (34). In a population of 162 patients who had progressed on first-line CisGem, the addition of mFOLFOX improved OS $(\mathrm{HR}=0.69, p=0.031)$ with a modest benefit $(6.2$ months $v s .5 .3$ months) and an increase of $14-15 \%$ in OS rates at 6 and 12 months. High-grade toxicities (especially G3-G4 fatigue, neutropenia and infections) were more frequent in the experimental arm (59\% vs. $39 \%$ in control arm), while the frequency of neuropathy and febrile neutropenia remained low (1\%). This positive study provided the first level-1 evidence for second-line treatment after standard-of-care first-line therapy. Therefore, although the absolute median OS differences between the two arms were modest, mFOLFOX is actually considered as new standard of care second-line chemotherapy for BTC patients with no driver mutations and whose disease progressed after CisGem.

Lastly, novel chemotherapy combinations have been tested for patients with BTC. Recently, a single-arm two-stage phase II trial evaluated the efficacy of FOLFIRINOX with two different dosages (standard and modified) in 40 patients who had disease progression or unacceptable toxicity after $\geq 3$ cycles of CisGem (35). The median PFS and OS in all patients was 6.2 and 10.7 months, respectively; the most common grade 3-4 adverse events were neutropenia, diarrhea, nausea, vomiting and mucositis.

\section{Targeted Therapy}

\section{FGFR2}

In iCCA, the FGFR signaling pathway is aberrantly activated in approximately 15 to $20 \%$ of cases and the most common FGFR pathway aberrations are gene fusions involving FGFR2 (36-38). Interestingly, iCCAs harboring FGFR2 fusions have been historically associated with female sex, younger age and prolonged survival (39). Multiple FGFR tyrosine kinase inhibitors (TKIs) are being assessed as second- or later-line treatment for patients with advanced 


\section{ADVANCED / METASTATIC BTC}

Tumor profiling, MS status, PD-L1 expression, MMR, TMB

\section{FIRST-LINE TREATMENT}
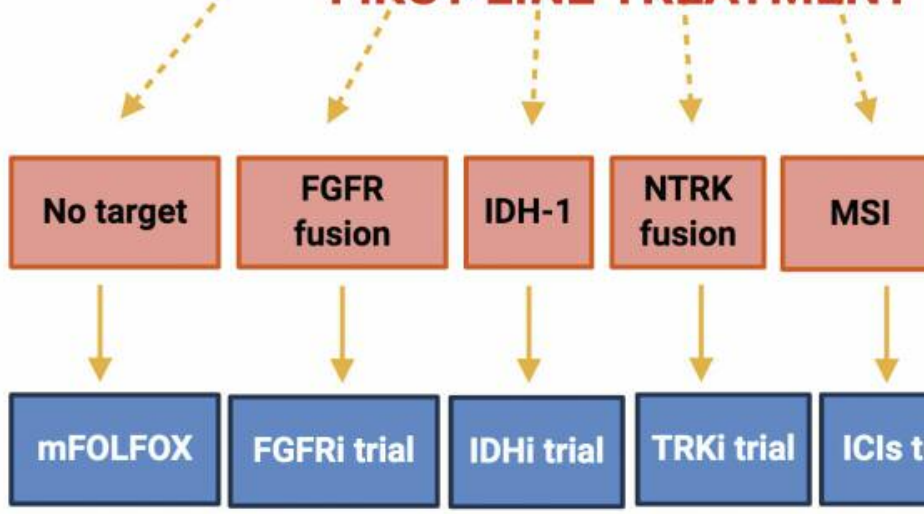

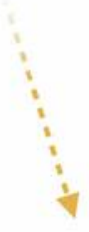

Figure 1. Current landscape of second-line treatment for biliary tract cancer (BTC).

FGFR-mutant iCCA, including infigratinib (BGJ398), derazantinib (ARQ-087), erdafitinib, pemigatinib (INCB054828), TAS-120 and rogaratinib (BAY1163877).

Infigratinib (BGJ398) showed meaningful clinical efficacy in a phase II trial on chemotherapy refractory iCCA harboring FGFR aberrations (40). In this trial, ORR was $14.8 \%$ (18.8\% in FGFR2 fusion group), DCR $75.4 \%$ (83.3\% FGFR2 fusions only) and median PFS 5.8 months (95\% CI=4.3-7.6) in 61 patients. Most frequent treatmentrelated adverse events included hyperphosphatemia, alopecia, stomatitis, palmar-plantar erythrodysesthesia and fatigue (40). Another phase II study on infigratinib in second- or later-line setting in patients with advanced CCA harboring FGFR2 gene fusions or translocations or other FGFR genetic alterations is currently ongoing (NCT02150967).

Derazantinib (ARQ087), an orally bioavailable multikinase inhibitor with potent activity against FGFR1, FGFR2 and FGFR3 kinases, showed promising anti-tumor activity and a favorable safety profile in patients with advanced FGFR2 fusion-positive iCCA in a phase I/II trial (41). Twenty-nine patients were enrolled ( 2 treatment naïve and 27 who had received at least one prior chemotherapy regimen); median PFS was 5.7 months (95\%CI=4.04-9.2 months), ORR $20.7 \%$ and DCR $82.8 \%$. Commonly observed adverse events were hyperphosphatemia, ocular toxicity, asthenia, and increase in ALT/AST. A phase II trial assessing derazantinib in iCCA patients who received at least one prior regimen of systemic therapy is ongoing (NCT03230318).

In a recent phase I trial, the pan-FGFR inhibitor erdafitinib was associated with promising clinical activity in advanced solid tumors with genomic alterations in the FGFR pathway, including iCCA (42). There are currently ongoing trials evaluating the safety and efficacy of erdafitinib in previously treated solid malignancies (NCT02699606, NCT04083976).

In FIGHT-202 trial, the pan-FGFR inhibitor pemigatinib (INCB054828) showed interesting results in previously treated patients affected by FGFR2 fusion-positive iCCA (43). More specifically, $38(35.5 \%)$ of 107 patients with FGFR2 rearrangements or fusions achieved an objective response (35 PRs and $3 \mathrm{CRs})$ and $88(82 \%)$ of 107 patients achieved disease control, with a median PFS of 6.9 months. Similarly to infigratinib and derazantinib, hyperphosphatemia was the most common all-grade adverse event [88 (60\%) of 146 patients], with other common adverse events which included arthralgia, stomatitis, hyponatremia, alopecia, diarrhea and fatigue. A phase II study investigating pemigatinib in patients with advanced/metastatic or surgically unresectable iCCA with 
FGFR2 rearrangement and which have failed at least one prior systemic chemotherapy is ongoing (NCT04256980).

TAS-120 is a highly potent, irreversible and selective inhibitor of FGFR1-4. In the dose-escalation phase of a phase I study, TAS-120 showed a tolerable safety profile and preliminary antitumor activity in pretreated patients with FGFR2 fusion-positive iCCA (44). The dose-expansion phase and a phase II trial are currently ongoing (NCT02052778).

Phase I and II trials regarding FGFR inhibitors E7090 (NCT04238715), CPL304110 (NCT04149691), EOC317 (NCT03583125) and INCB062079 (NCT03144661) are ongoing, with the aim to explore novel therapeutic chances in pretreated FGFR-positive iCCA.

Notwithstanding evidence from the initial efficacy of FGFR2 inhibitors, almost all patients develop acquired resistance, something which represents a major concern in FGFR targeted therapy (45).

Table I summarizes ongoing trials on FGFR targeted therapy in BTC registered on clinicaltrials.gov.

\section{IDH1}

IDH mutations are reported in 19-36\% of iCCAs, representing not only an exclusive mutation to iCCA subtype but also the most frequent in this subgroup (46). IDHI and $I D H 2$ point mutations result in 2-hydroxyglutarate $(2-\mathrm{HG})$ accumulation, which can be directly detected in the bloodstream and seems to play a pivotal role in carcinogenesis (47). From an epidemiological point of view, IDH mutations appear to be more common in non Opistorchis Viverrini-related iCCAs compared with noninfectious forms (48).

Following the results of preclinical studies $(49,50)$, a phase I trial assessed the role of the first-in-class oral IDH1 inhibitor ivosidenib (AG-120) in pretreated, IDH1-mutated, metastatic malignancies including 73 cases of iCCA (51). Stable disease (SD) and partial response (PR) were achieved in $56 \%$ and $5 \%$ of patients, respectively; median PFS was 3.8 months $(95 \% \mathrm{CI}=3.6-7.3)$ and median OS 13.8 months $(95 \% \mathrm{CI}=11.1-29.3)$, with a manageable safety profile and no dose-limiting toxicities. Interestingly, a reduction in Ki67 nuclear staining and in circulating 2-HG levels were detected in ivosidenib responders (51).

The results of the phase III, randomized, placebocontrolled, ClarIDHy trial were presented at the 2019 ESMO Congress (52); in this study, iCCA patients harboring IDHI mutations and who had received one or two prior lines of therapy, were randomized to $500 \mathrm{mg}$ ivosidenib once daily or a matched placebo. The ivosidenib arm achieved a median PFS of 2.7 months versus 1.4 months of the placebo group, with a median PFS rate at 6 months of $32 \%$ and $21.9 \%$, respectively (52). According to the intention-to-treat analysis, median OS was 10.8 months in patients treated with ivosidenib compared to 9.7 months with placebo. Finally, a favorable safety profile was observed in the ivosidenib arm, in concordance with previous studies in this setting. Thus, despite providing a modest OS benefit, ivosidenib represents a promising candidate in future second-line setting for CCA patients harboring $I D H I$ mutations.

There are currently ongoing trials testing the safety and efficacy of other IDH inhibitors such as BYA143602, IDH305, FT 21012 and AG-881 (NCT02481154, NCT02746081, NCT02381886, NCT03684811).

Finally, preclinical models recently suggested that 2-HG enhances $I D H$-mutant CCA cells sensitivity to PARP inhibitors, since 2-HG can also prevent homologous recombination inducing a "BRCAness" phenotype (see below) (53). Thus, a phase II trial is currently ongoing with the aim to evaluate the PARP inhibitor olaparib in refractory, IDH-mutant solid tumors (NCT03212274).

\section{EGFR/HER2}

The epidermal growth factor receptor (EGFR) signaling seems to play a crucial role in BTC tumorigenesis since EGFR is frequently overexpressed in BTC, especially in iCCA (38-100\%) (54). Although initial preclinical studies have shown promising results and have paved the way for RCTs in BTC, many trials evaluating EGFR inhibitors as monotherapy or in combination with other anticancer agents have produced modest benefit with short-lived, disappointing responses (55). Moreover, the majority of these studies focused on first-line therapy and only a small part of them assessed EGFR inhibitors in the second-line setting (56).

The EGFR TKI erlotinib was firstly evaluated as monotherapy in a phase II trial enrolling metastatic BTC patients who had received one prior line of therapy (57). In this study, 7 of 42 patients were progression-free at 6 months (17\%; 95\% CI=7-31\%) and 3 patients achieved PR. Erlotinib was also tested in combination with docetaxel and sorafenib, and these combination strategies failed to show any PFS and OS benefit compared with single agent erlotinib (58-60).

Data regarding the EGFR antibodies cetuximab and panitumumab belong only to first-line setting since previous trials have shown disappointing results which do not support further studies on second- or later line of treatment (61-66). Finally, chimeric antigen receptor-modified T (CART)-EGFR cell therapy has been tested on EGFR-positive advanced BTC in a recent phase I trial (67). In this study, 19 patients (14 CCAs and 5 GBCs) received CART-EGFR after conditioning treatment with nab-paclitaxel and cyclophosphamide. Of 17 evaluable patients, 1 subject achieved CR and 10 patients SD; median PFS was 4 months, ranging from 2.5 to 22 months, with a tolerable safety profile (67).

With regard to HER2, HER2 amplification and overexpression are found in approximately 5-15\% of eCCAs 
Table I. Current ongoing trials involving FGFR targeted therapy as second-line treatment registered on clinicaltrials.gov.

\begin{tabular}{|c|c|c|c|c|c|c|c|}
\hline NCT04256980 & $\begin{array}{l}\text { Pemigatinib in treating } \\
\text { patients with advanced/ } \\
\text { metastatic or surgically } \\
\text { unresectable CCA including } \\
\text { FGFR2 rearrangement }\end{array}$ & $\begin{array}{l}\text { Not yet } \\
\text { recruiting }\end{array}$ & $\mathrm{CCA}$ & $\begin{array}{l}\text { Second- or } \\
\text { later-line }\end{array}$ & $\begin{array}{c}\text { Drug: } \\
\text { Pemigatinib }\end{array}$ & 2 & $\begin{array}{c}\text { February } \\
2020\end{array}$ \\
\hline NCT04238715 & $\begin{array}{l}\text { A study of E7090 in } \\
\text { participants with unresectable } \\
\text { advanced or metastatic CCA } \\
\text { with } F G F R 2 \text { gene fusion }\end{array}$ & Recruiting & $\mathrm{CCA}$ & $\begin{array}{l}\text { Second- or } \\
\text { later-line }\end{array}$ & $\begin{array}{l}\text { Drug: } \\
\text { E7090 }\end{array}$ & 2 & $\begin{array}{c}\text { January } \\
2020\end{array}$ \\
\hline NCT04233567 & $\begin{array}{l}\text { Infigratinib for the treatment } \\
\text { of advanced or metastatic } \\
\text { solid tumors in patients with } \\
\text { FGFR gene mutations }\end{array}$ & Recruiting & $\begin{array}{l}\text { Advanced } \\
\text { FGFR-positive } \\
\text { solid malignancies } \\
\text { including CCA }\end{array}$ & $\begin{array}{l}\text { Second- or } \\
\text { later-line }\end{array}$ & $\begin{array}{c}\text { Drug: } \\
\text { Infigratinib }\end{array}$ & 2 & $\begin{array}{c}\text { January } \\
2020\end{array}$ \\
\hline NCT04149691 & $\begin{array}{l}\text { Safety, tolerability and } \\
\text { pharmacokinetics of oral } \\
\text { CPL304110, in adult } \\
\text { subjects with advanced } \\
\text { solid malignancies }\end{array}$ & Recruiting & $\begin{array}{l}\text { Advanced } \\
\text { solid } \\
\text { malignancies } \\
\text { including CCA }\end{array}$ & $\begin{array}{l}\text { Second- or } \\
\text { later-line }\end{array}$ & $\begin{array}{c}\text { Drug: } \\
\text { CPL304110 }\end{array}$ & 1 & $\begin{array}{l}\text { July } \\
2019\end{array}$ \\
\hline NCT03583125 & $\begin{array}{l}\text { Study of EOC } 317 \text { in } \\
\text { Chinese patients with } \\
\text { advanced solid tumors }\end{array}$ & Recruiting & $\begin{array}{l}\text { Advanced } \\
\text { FGFR-positive } \\
\text { solid malignancies } \\
\text { including CCA }\end{array}$ & $\begin{array}{l}\text { Second- or } \\
\text { later-line }\end{array}$ & $\begin{array}{l}\text { Drug: } \\
\text { EOC317 }\end{array}$ & 1 & $\begin{array}{l}\text { May } \\
2018\end{array}$ \\
\hline NCT03230318 & $\begin{array}{l}\text { Derazantinib in subjects } \\
\text { with } F G F R 2 \text { gene fusion-, } \\
\text { mutation- or amplification- } \\
\text { positive inoperable or } \\
\text { advanced iCCA }\end{array}$ & Recruiting & $\begin{array}{c}\bullet \text { iCCA } \\
\bullet \text { Combined } \\
\text { Hepatocellular and } \\
\text { Cholangiocarcinoma }\end{array}$ & $\begin{array}{l}\text { Second- or } \\
\text { later-line }\end{array}$ & $\begin{array}{c}\text { Drug: } \\
\text { derazantinib }\end{array}$ & 2 & $\begin{array}{c}\text { November } \\
2017\end{array}$ \\
\hline NCT03144661 & $\begin{array}{l}\text { An open-label safety } \\
\text { and tolerability study of } \\
\text { INCB062079 in subjects } \\
\text { with advanced HCC } \\
\text { and othermalignancies }\end{array}$ & Recruiting & $\begin{array}{l}\text { Advanced } \\
\text { FGFR-positive } \\
\text { solid malignancies } \\
\text { including CCA }\end{array}$ & $\begin{array}{l}\text { Second- or } \\
\text { later-line }\end{array}$ & $\begin{array}{c}\text { Drug: } \\
\text { INCB062079 }\end{array}$ & 1 & $\begin{array}{l}\text { May } \\
2017\end{array}$ \\
\hline NCT02393248 & $\begin{array}{c}\text { Open-label, dose-escalation } \\
\text { study of pemigatinib in subjects } \\
\text { with advanced malignancies - } \\
\text { (FIGHT-101) }\end{array}$ & Recruiting & $\begin{array}{l}\text { Advanced } \\
\text { FGFR-positive } \\
\text { solid malignancies } \\
\text { including CCA }\end{array}$ & $\begin{array}{l}\text { Second- or } \\
\text { later-line }\end{array}$ & $\begin{array}{c}\text { Drug: } \\
\text { Pemigatinib } \\
\text { (alone or in } \\
\text { combination } \\
\text { with other } \\
\text { anticancer } \\
\text { agents) }\end{array}$ & $1 / 2$ & $\begin{array}{l}\text { January } \\
2015\end{array}$ \\
\hline NCT02699606 & $\begin{array}{l}\text { A study to evaluate the clinical } \\
\text { efficacy of JNJ-42756493 } \\
\text { (erdafitinib), a pan-fibroblast } \\
\text { growth factor receptor } \\
\text { (FGFR) tyrosine kinase } \\
\text { inhibitor, In Asian participants } \\
\text { with advanced NSCLC, urothelial } \\
\text { cancer, esophageal cancer or } \\
\text { CCA }\end{array}$ & Recruiting & $\begin{array}{l}\text { Advanced } \\
\text { FGFR-positive } \\
\text { solid malignancies } \\
\text { including CCA }\end{array}$ & $\begin{array}{l}\text { Second- or } \\
\text { later-line }\end{array}$ & $\begin{array}{c}\text { Drug: } \\
\text { Erdafitinib }\end{array}$ & 2 & $\begin{array}{l}\text { July } \\
2016\end{array}$ \\
\hline NCT04083976 & $\begin{array}{c}\text { A study of erdafitinib } \\
\text { in participants with advanced } \\
\text { solid tumors and } \\
F G F R \text { gene alterations }\end{array}$ & Recruiting & $\begin{array}{l}\text { Advanced } \\
\text { FGFR-positive } \\
\text { solid malignancies } \\
\text { including CCA }\end{array}$ & $\begin{array}{l}\text { Second- or } \\
\text { later-line }\end{array}$ & $\begin{array}{c}\text { Drug: } \\
\text { Erdafitinib }\end{array}$ & 2 & $\begin{array}{c}\text { November } \\
2019\end{array}$ \\
\hline NCT02150967 & $\begin{array}{c}\text { A phase II, single arm study } \\
\text { of BGJ398 in patients with } \\
\text { advanced CCA }\end{array}$ & Recruiting & $\mathrm{CCA}$ & $\begin{array}{l}\text { Second- or } \\
\text { later-line }\end{array}$ & $\begin{array}{c}\text { Drug: } \\
\text { BGJ398 } \\
\text { (infigratinib) }\end{array}$ & 2 & $\begin{array}{l}\text { July } \\
2014\end{array}$ \\
\hline NCT02052778 & $\begin{array}{l}\text { A study of TAS-120 in } \\
\text { patients with advanced } \\
\text { solid tumors }\end{array}$ & $\begin{array}{c}\text { Active, } \\
\text { not recruiting }\end{array}$ & $\begin{array}{l}\text { Advanced } \\
\text { FGFR-positive } \\
\text { solid malignancies } \\
\text { including CCA }\end{array}$ & $\begin{array}{l}\text { Second- or } \\
\text { later-line }\end{array}$ & $\begin{array}{l}\text { Drug: } \\
\text { TAS-120 }\end{array}$ & $\begin{array}{c}1 \\
2014\end{array}$ & July \\
\hline
\end{tabular}

CCA: Cholangiocarcinoma; FGFR: fibroblast growth factor receptor. 
and GBCs, thus representing a frequent aberration in these two subgroups (68-71). The blockade of HER2 signaling significantly improved the outlook of breast and esophagogastric cancer and targeting the HER2 family pathway has become increasingly attractive in several other malignancies, including BTC $(72,73)$.

The MyPathway basket trial included 11 patients affected by previously treated BTC harboring HER2 amplification/overexpression $(n=8)$ and mutation $(n=3)$; in this trial, the combination of trastuzumab plus pertuzumab yielded a response rate of $7.5 \%$ and $33.3 \%$ in HER2 amplified and mutated patients, respectively (74).

The SUMMIT basket trial is currently exploring the efficacy and safety of the pan-HER kinase inhibitor neratinib (NCT01953926) in patients with solid tumors harboring HER2, HER3 or EGFR mutations / amplification (75). In this trial, preliminary results have shown an objective response rate of $10 \%$ among the subgroup of BTC patients $(n=20)$ included (76), with $74 \%$ of the BTC study's population comprising patients whose disease progressed after treatment with gemcitabine and platinum-containing regimens.

Another recent trial showed a PR of $27 \%, \mathrm{SD}$ of $43 \%$ and DCR of $70 \%$ in 37 BTC patients receiving the pan-HER TKI varlitinib in combination with cytotoxic chemotherapy (77). The study included patients affected by CCA $(74.4 \%)$, GBC (16.3\%) and AVC (9.3\%), of which 32.6\% (14 subjects) had received at least one prior line of treatment. Conversely, studies regarding other pan-HER inhibitors such as lapatinib and afatinib have not shown positive results in BTC $(78,79)$.

There are currently ongoing trials assessing the role of HER2-targeted therapies in BTC, especially as front-line treatment in combination with systemic chemotherapy (NCT03613168, NCT02992340 NCT02836847). With regard to second-line treatment, the TreeTopp (NCT03093870) trial is investigating the efficacy of varlitinib plus capecitabine versus capecitabine plus placebo in patients who have received and failed one prior line of systemic treatment. In the same setting, a phase II trial is currently evaluating trastuzumab plus chemotherapy in previously treated HER2 positive patients (NCT03185988).

\section{Angiogenesis Inhibitors}

Angiogenesis and lymphangiogenesis are considered essential processes in BTC tumorigenesis (80-83). The importance of angiogenesis in BTC has led to several preclinical and phase I and II trials targeting the vascular endothelial growth factor (VEGF) pathway with antibodies (bevacizumab, ramucirumab, aflibercept) and TKIs (vandetanib, sorafenib, sunitinib, cediranib, regorafenib, selumetinib, apatinib), as monotherapy or in association with chemotherapy or other anticancer agents (84).
A recent phase II trial investigated the association of capecitabine, irinotecan, gemcitabine and bevacizumab as a second-line treatment in 50 patients with metastatic cholangiocarcinoma (85); in this study, median PFS was 3.6 months and median OS 6.4 months.

The role of the TKI sunitinib (86), was assessed in a multicenter phase II study (SUN-CK trial), where secondline treatment sunitinib was administered in 53 patients with advanced iCCA (87). Twenty-four patients experienced SD (71\%) and 5 patients PR (15\%), with median OS and PFS of 9.6 and 5.2 months, respectively. The most common adverse events were asthenia, mucositis, hypertension, diarrhea and hand-foot syndrome.

Lenvatinib monotherapy was evaluated as second-line treatment in unresectable BTC in a phase II trial (88). In this trial, primary analysis was performed with data on 26 patients, where lenvatinib yielded a DCR of $85 \%$ and $46 \%$ by an investigator and independent review, respectively. Median PFS was 3.2 months by investigator review and 1.6 months by independent review; lastly, median OS was 7.4 months.

In a phase I trial, the combination of ramucirumab, a human monoclonal antibody against VEGFR-2 (89), plus pembrolizumab suggested limited clinical activity in 26 heavily pretreated CCA patients (90). The most common adverse events were hypertension, fatigue, diarrhea, nausea and hypothyroidism (90). ORR was $4 \%$ while median PFS and OS 1.6 months and 6.4 months, respectively (90). A phase II trial evaluating the role of ramucirumab monotherapy in pretreated patients with metastatic CCA is recruiting patients (NCT02520141).

Another VEGFR-2 inhibitor, apatinib, is currently under investigation as second-line therapy in an ongoing phase II study (NCT03521219).

Regorafenib monotherapy was evaluated in a phase II trial on 37 BTC patients whose disease progressed after first-line chemotherapy (91). In this study, 3 patients had PR (10.7\%) and 18 experienced SD (4.3\%), with DCR of $75 \%$. Median PFS and OS was 3.55 months and 5.55 months, respectively, with a favorable safety profile. The most common adverse events were hypophosphatemia, hand-foot skin reaction, hypertension and increased serum bilirubin. In another phase II trial regorafenib was studied in $39 \mathrm{CCA}$ patients which have failed one prior gemcitabine-based systemic therapy (92). Median PFS was 3.7 months and median OS 9.9 months, with PR achieved in 2 patients (6.2\%) and SD in 18 subjects $(56.2 \%)$. The most common toxicities were fatigue and hypertension, with dose adjustment required in $49 \%$ of the patients.

The TKI sorafenib was evaluated in a phase II trial (93) including 46 BTC patients, $26(56 \%)$ of which received sorafenib as second-line treatment. PFS was 2.3 months (range $=0-12$ months), and median OS was 4.4 months, 
showing an overall low activity (93). Performance status was significantly related to PFS since it was 5.7 months for ECOG PS 0 and 2.1 months for ECOG PS 1 subjects (93).

\section{RAF, MEK}

The mitogen-activated protein kinase (MAPK)/extracellular signal-regulated kinase (ERK), or Ras-Raf-MEK-ERK pathway, plays a crucial role in cell proliferation and survival (94). Strong activators of this pathway are $B R A F$ (v-Raf murine sarcoma viral oncogene homolog B) mutations, the most common of which is $B R A F \mathrm{~V} 600 \mathrm{E}$ (95). With regard to BTC, BRAF mutations are more frequent in iCCA compared with eCCA or GBC (96); more specifically, BRAF mutations have been reported in 1 to $22 \%$ of iCCAs in various population studies or cases series (96).

The BRAF V600 kinase inhibitor vemurafenib was tested in a phase II basket trial which enrolled previously treated patients with metastatic BRAF V600E mutated nonmelanoma cancers (97). In this study, vemurafenib monotherapy showed $12 \%$ ORR in $B R A F$-mutant CCA, with 1 out of 8 patients experiencing PR (97).

A phase II trial evaluated the MEK1/2 inhibitor selumetinib in 29 BTC patients, 39\% of which had previously received one prior systemic chemotherapy (98). Three objective responses were detected while 17 patients had SD [98]; additionally, median PFS was 3.7 months and median OS 9.8 months.

Trametinib, an oral highly selective inhibitor of MEK1/2, did not show significant activity as second line treatment in the SWOG S1310 trial (99), where trametinib was used in patients with advanced CCA after failure of GemCis chemotherapy. The trial was stopped prematurely given the lack of response observed in the trametinib arm.

The MEK1/2 selective inhibitor binimetinib was tested in a phase Ib trial on 28 CCA patients, in $43 \%$ of whom was used as a second-line treatment (100). Two patients experienced objective responses (1 CR, $1 \mathrm{PR}$ ) and 12 had SD. The most common adverse events were nausea, rash, vomiting, fatigue, diarrhea, peripheral edema and ocular toxicities. No correlation between mutational status and objective response was observed. In another phase Ib trial, binimetinib was studied in association with capecitabine in gemcitabinerefractory CCA patients (101). Seven out of 34 patients (20.6\%) showed PR and 19 (55.9\%) SD, with a median OS of 7.8 months. Interestingly, subjects harboring mutations in the RAS/RAF/MEK/ERK pathway showed a better response to therapy (40.0\% vs. 12.5\%), longer PFS (5.4 vs. 3.5 months) and better OS (10.8vs. 5.9 months) than wild type patients. On the basis of the well-known improved efficacy of double BRAF and MEK inhibition in melanoma and colorectal cancer, the combination of dabrafenib plus trametinib was evaluated in patients with $B R A F$ V600E- mutated CCA in a cohort of the ROAR basket trial. This phase II basket trial regarding 178 patients with $B R A F$ V600E mutated malignancies included also 33 patients with refractory BTC (102). In the cohort of BTC patients, promising results were reported since PR was detected in $42 \%$ of patients and SD in $45 \%$, with a favorable safety profile. Median PFS and median OS were 7.2 and 11.3 months, respectively.

\section{cMET}

The proto-oncogene c-MET plays an important role in carcinogenesis via promoting tumor invasion, angiogenesis, increased cell motility and antiapoptotic signals (103-105). MET amplification has been observed in 2-8\% of BTCs while high c-MET expression has been described in $15 \%$ of eCCA and $12 \%$ of iCCA, according to previous studies (106). cMET overexpression seems to represent a negative prognostic factor in BTC given the association with advanced stage at diagnosis and higher tumor volume $(107,108)$.

A recent phase II study evaluated the role of cabozantinib, a multikinase TKI targeting MET, in 19 previously treated CCA patients (109). In this trial, cabozantinib showed significant toxicity and limited activity, with a median PFS and $\mathrm{OS}$ of $1.8(95 \% \mathrm{CI}=1.6-5.4)$ and $5.2(95 \% \mathrm{CI}=2.7-10.5)$ months, respectively.

\section{Pi3k/AKT/mTOR}

Aberrations involving the PI3K/AKT/mTOR pathway are common in eCCA (40\%), iCCA (25\%) and GBC (4-16\%) patients $(110,111)$; these aberrations mainly include PI3KCA amplifications, PI3K mutations, phosphorylated AKT overexpression and phosphorylated mTOR overexpression (112-115). Several trials have investigated the role of PI3K, AKT and mTOR inhibitors in first- and second-line setting in BTC, with limited tumor responses and disappointing results (116).

The phase II trial assessing the role of second-line MK2206, an AKT selective inhibitor, was stopped prematurely, after the enrollment of 8 CCA patients (117). Median PFS was 1.7 months and median OS 3.5 months; two patients reported SD (25\%) and $6 \mathrm{PD}(75 \%)$ as best response.

The mTOR inhibitor everolimus was tested in a phase II study (EUDRACT 2008-007152-94) on 39 CCA patients refractory to first-line therapy (118). In this trial, ORR and DCR were $5.1 \%$ and $44 \%$ respectively, with a median PFS of 3.2 months and a median OS of 7.7 months.

Several ongoing trials are currently exploring the role of combination or sequential strategies using dual AKT-mTOR blockade or PI3K-mTOR inhibitors plus systemic chemotherapy in order to overcome resistance mechanisms related to the use of single targeted agents (NCT02465060, 
Table II. Current ongoing trials involving PARP inhibitors as second-line treatment in BTC registered on clinicaltrials.gov.

\begin{tabular}{|c|c|c|c|c|c|}
\hline NCT number & Cohort & $\begin{array}{l}\text { Therapeutic } \\
\text { regimen }\end{array}$ & Design & $\begin{array}{l}\text { DDR defect } \\
\text { screening }\end{array}$ & $\begin{array}{l}\text { Primary } \\
\text { endpoint }\end{array}$ \\
\hline NCT03212274 & $\begin{array}{l}\text { Refractory and metastatic cholangiocarcinoma } \\
\text { with } I D H 1 \text { or } I D H 2 \text { mutation }\end{array}$ & Olaparib & Phase 2 & No & ORR \\
\hline NCT03207347 & $\begin{array}{l}\text { Advanced or metastatic CCA after prior } \\
\text { standard systemic treatment }\end{array}$ & Niraparib & Phase 2 & Yes & ORR \\
\hline NCT03991832 & $\begin{array}{l}I D H \text {-mutated BTC after no more than } \\
2 \text { previous treatment }\end{array}$ & $\begin{array}{c}\text { Olaparib }+ \\
\text { durvalumab }\end{array}$ & Phase 2 & No & ORR \\
\hline NCT03878095 & $\begin{array}{l}I D H \text {-mutated CCA or other solid malignancy } \\
\text { after prior standard treatment or } \\
\text { with no available treatment }\end{array}$ & $\begin{array}{l}\text { Olaparib + } \\
\text { ceralasertib }\end{array}$ & Phase 2 & No & $\begin{array}{l}\text { ORR } \\
\text { DCR }\end{array}$ \\
\hline NCT03639935 & BTC after prior standard systemic treatment & $\begin{array}{c}\text { Rucaparib + } \\
\text { nivolumab }\end{array}$ & Phase 2 & No & $\begin{array}{l}\text { Proportion } \\
\text { of patients } \\
\text { alive and } \\
\text { without PD } \\
\text { at } 4 \text { months }\end{array}$ \\
\hline NCT04042831 & $\begin{array}{l}\text { BTC with somatic/germline mutations } \\
\text { in DDR genes after exposure/completion } \\
\text { of platinum-based chemotherapy }\end{array}$ & Olaparib & Phase 2 & Yes & ORR \\
\hline
\end{tabular}

ORR: Overall response rate; DCR: disease control rate.

NCT02836847, NCT02631590) (119). Given the extensive crosstalk characterizing the PI3K/AKT/mTOR pathway and the connections with several other pathways and networks regulating cancer proliferation and progression, combination strategies based on resistance mechanisms and co-occurring drivers could be the keys for the successful development of agents targeting this pathway (120).

\section{PARP}

Poly adenosine diphosphate-ribose polymerase inhibitors (PARPis) represent an emerging therapeutic class for cancer patients harboring germline and somatic aberrations in DNA damage repair (DDR) genes (121). In BTCs, alterations in DDR genes have been identified in 28 up to $63 \%$ of patients, including mutations in $A T M, A T R, B A P 1, B R C A 1, B R C A 2$, BARD1, BRIP1, CHEK2, ARIDIA, MLH1, MSH2, MSH6, PALB2, RAD50, FANCA and FANCD2 $(122,123)$. BRCA1 and $B R C A 2$ are the most well-known DDR genes and BRCA $1 / 2$ mutations occur in $1-7 \%$ of BTC patients $(124,125)$. In a retrospective analysis by Golan et al., 4 of 18 CCA patients with a confirmed $B R C A$ mutation were treated with PARPis with a favorable response in first or further lines (125), and interestingly, $44 \%$ of patients ( 8 of 18 ) had a previous tumor or a family history of BRCA-associated malignancies (breast, ovarian, prostate and pancreatic cancer). Nevertheless, there is a lack of consensus regarding which BTC patients should be tested for $B R C A 1 / 2$ mutations and the optimal therapeutic strategy in BTC tumors harboring homologous repair deficiency (HRD) alterations is yet to be defined. With regard to second-line setting, few data are available supporting the efficacy of PARPis in second and further lines, given the absence of RCTs evaluating these agents.

Moreover, it would be important to understand the real prevalence of germline and somatic DDR mutations in BTCs across populations and further studies are needed to classify tumors as DNA-repair deficient, therefore screening groups with different genetic backgrounds is required. Ongoing clinical trials are aimed at identifying which genetic alterations are most likely to benefit from DNA-damaging therapies and are testing the combination of PARPis with various agents including chemotherapy, ICIs and small molecule inhibitors targeting various signaling pathways $(126,127)$. Table II summarizes ongoing trials on PARPis as second-line therapy in BTC registered on clinicaltrials.gov.

\section{NTRK}

Gene fusions involving NTRK1, NTRK2 and NTRK3 genes (encoding the neurotrophin receptors TRKA, TRKB and TRKC, respectively) occur in a broad range of adult and pediatric cancers $(128,129)$. Larotrectinib (LOXO-101) is a first-in-class potent and highly selective TRK inhibitor, which has shown promising clinical activity in patients with tumors harboring NTRK gene fusions (130, 131). The landmark study assessing the role of larotrectinib showed an ORR of $75 \%(95 \% \mathrm{CI}=61-85 \%)$ with an acceptable safety profile in 55 NTRK-positive malignancies, including 2 cases of previously treated CCA (132). At the time of primary data cutoff, 7 patients (13\%) achieved CR and 34 (62\%) PR; 
moreover, $71 \%$ of patients had ongoing response and $55 \%$ were progression-free at 1 year. The results of this study led to the approval of larotrectinib by the FDA (November 2018) and EMA (September 2019) for the treatment of pediatric and adult patients with NTRK-positive, locally advanced or metastatic solid tumors, which progressed after standard treatments and/or have no satisfactory alternative treatments (133). Larotrectinib is being assessed in the phase II NAVIGATE basket trial, which is enrolling NTRK-fusion positive solid malignancies, including patients affected by BTC (NCT02576431). Similarly, the TRK inhibitor entrectinib (RDX-101) is currently under investigation in an ongoing phase II basket trial on metastatic solid tumors, including CCA (STARTRK-2, NCT02568267). Additional data from these clinical trials will help to confirm the activity of TRK inhibitors in NTRK-positive malignancies and possibly to expand their use for tumor-agnostic treatments $(134,135)$. Since recent studies have reported a $4 \%$ frequency of NTRK fusion in iCCA and in light of the modest benefit of alternative treatment options, testing patients for NTRK aberration may be a reasonable strategy in this setting $(136,137)$.

\section{Immunotherapy}

The introduction of ICIs has revolutionized the treatment of several hematological and solid malignancies in the last decade (138-140). In this landscape, tumour mutational burden (TMB), programmed death ligand 1 (PD-L1) protein expression, mismatch repair deficiency (dMMR) and instable microsatellite (MSI) phenotype are currently considered important markers of response to immunotherapy (141). Higher TMB is associated with better response to ICIs in a number of solid tumours, and similarly, a wide range of studies have suggested a correlation between dMMR / MSIhigh phenotype and ORR and PFS rates in patients receiving ICIs (142). Based on these findings, in 2017, the FDA approved pembrolizumab for the treatment of any MSI-high or dMMR malignancies, regardless of histology (143).

With regard to BTC, important differences in terms of aetiology, immune-microenvironment and genetic features exist among the anatomical subgroups, and these differences may be implicated in the clinical response to ICIs. Furthermore, recent studies have suggested that approximately $3 \%$ of BTCs presents a high TMB or dMMR phenotype $(144,145)$.

The anti-PD-1 agent pembrolizumab was firstly evaluated in the phase Ib KEYNOTE-028 trial (146). In this study, 24 pretreated patients with PD-L1 positive BTCs (20 CCAs and 4 GBCs) were enrolled and treated with pembrolizumab monotherapy; 4 (17\%) patients achieved PR and 4 (17\%) had SD. More recently, the KEYNOTE-158 trial (NCT02628067) tested the use of pembrolizumab in $104 \mathrm{CCA}$ and GBC patients with disease progression after at least one prior treatment regimen. The trial included no MSI-high tumors while the $60 \%$ of patients were PD-L1 positive, considering the cutoff of $1 \%$ of PD-L1 expression. In this study, ORR for unselected patients was $5.8 \%$, with a median OS and PFS of 7.4 and 2.0 months, respectively (147).

Pembrolizumab is also under investigation in several ongoing trials on second- and further-line settings (NCT02703714, NCT03695952, NCT04234113). A singlearm, phase II trial (NCT03110328) is testing the role of pembrolizumab in patients with metastatic BTC as secondline treatment after systemic chemotherapy, regardless of PD-L1 expression.

Another anti-PD-1 agent, nivolumab, has been studied in a recent phase II trial involving 54 BTC patients; in this trial, nivolumab obtained an ORR of $22 \%$ and a median OS of 14.24 months (148). The study enrolled patients after failure of at least one standard treatment regimen for BTC.

The anti-PD-L1 agent durvalumab was tested as monotherapy and in combination with tremelimumab in a phase I trial on pretreated, Asian BTC patients (149). Median duration of response for the durvalumab and the durvalumab plus tremelimumab cohorts were 9.7 and 8.5 months, respectively. Moreover, median OS was 8.1 months (95\% CI=5.6-10.1) in patients receiving durvalumab and 10.1 months $(95 \% \mathrm{CI}=6.2-11.4)$ in the durvalumab plus tremelimumab combination.

Since combining ICIs to targeted therapies or systemic chemotherapy is an emerging approach in a spectrum of malignancies, this strategy is under evaluation also in BTC. More specifically, combination therapies may play a role in changing immune cell infiltrate, thus enhancing the efficacy of ICIs, as suggested in preclinical models.

The association between the VEGFR-2 inhibitor ramucirumab and pembrolizumab was analyzed in a phase I trial on 26 previously treated metastatic BTCs, where the combination yielded an ORR of $4 \%$ while median PFS and OS were 1.6 and 6.4 months, respectively (150).

Another recent phase II trial studied the association of lenvatinib plus pembrolizumab or nivolumab in 14 iCCA patients who had received at least two prior anticancer treatments. ORR and DCR were $21.4 \%$ and $92.9 \%$, respectively, with a median PFS of 5.9 months $(95 \% \mathrm{CI}=4.2-$ 6.2) (151).

The combination of pembrolizumab plus lenvatinib is also under evaluation in the phase II LEAP-005 trial, which is enrolling previously treated patients with solid malignancies, including BTC (NCT03797326). Similarly, the combination of pembrolizumab plus CAPOX (capecitabine plus oxaliplatin) regimen is being assessed in an ongoing phase II trial on previously treated BTC patients (NCT03111732). Table III summarizes ongoing trials on ICIs as second-line treatment in BTC registered on clinicaltrials.gov. 
Table III. Current ongoing trials involving ICIs as second-line treatment in BTC registered on clinicaltrials.gov.

\begin{tabular}{|c|c|c|c|c|c|}
\hline NCT number & Status & Therapeutic regimen & Checkpoint target & Setting & Phase \\
\hline NCT03260712 & Not yet recruiting & Pembrolizumab & PD-1 & Second-line & 2 , single-arm \\
\hline NCT03046862 & Recruiting & Durvalumab + tremelimumab & PD-1, CTLA-4 & Second-line & 2 , single-arm \\
\hline NTC03101566 & Recruiting & Nivolumab + ipilimumab & PD-1, CTLA-4 & Second-line & 2, open-label \\
\hline NCT03668119 & Recruiting & Nivolumab + ipilimumab & PD-1, CTLA-4 & TMB high solid tumors & 2, open-label \\
\hline NCT02923934 & Recruiting & Nivolumab + ipilimumab & PD-1, CTLA-4 & Second-line or more & 2 , single-arm \\
\hline NCT02834013 & Recruiting & Nivolumab + ipilimumab & PD-1, CTLA-4 & Second-line or more & 2 , single-arm \\
\hline NCT02829918 & Active, not recruiting & Nivolumab & PD-1 & Second-line & 2 , single-arm \\
\hline NCT03111732 & Recruiting & Pembrolizumab + CAPOX & PD-1 & Second-line or more & 2 , single-arm \\
\hline NCT01174121 & Recruiting & $\begin{array}{c}\text { Pembrolizumab + } \\
\text { autologous TILs }\end{array}$ & PD-1, TIL & $\begin{array}{c}\text { Metastatic cancer } \\
\text { including BTC }\end{array}$ & 2, multi-arm \\
\hline
\end{tabular}

\section{The Clinical Background: What we Should Remember}

As previously stated, many BTC patients receiving first-line treatment fail to achieve a response and, even in responders, responses are short lived $(1,3)$. In this setting, medical oncologists are faced with the vexing decision to treat the "inevitable" tumor progression in patients with frequently declining performance status $(4,5)$. However, a nonnegligible number of BTC patients are still medically fit to be offered second-line therapy and there is an increasing use of systemic treatments beyond first line setting $(8,9)$. Thus, understanding which BTC patients may benefit from secondline therapy is of growing interest and several prognostic factors have been recently suggested to influence clinical outcomes in second-line treatment (14). In an Italian, multicenter, retrospective study involving 811 patients with advanced BTC, 357 subjects (44\%) received a second-line therapy (13), $25 \%$ of whom received fluoropyrimidine monotherapy and $32 \%$ a platinum-based schedule. In this study, patients who achieved a first line PFS ${ }^{3} 6$ months had better prognosis compared with those who did not. Moreover, Eastern Cooperative Oncology Group (ECOG) performance status (PS), CA19.9 levels, and previous surgery were independently associated with longer OS. The association between previous surgery and good ECOG-PS $(0-1)$ with better survival has been recently suggested also by a large international multicenter study with 797 patients (152). Peritoneal carcinomatosis was an independent prognostic factor for OS, according to the results of the study. However, prognostic factors in second-line treatment are currently subject to debate and remain unclear.

Evidently, the use of second-line treatment should be considered in suitably motivated patients with good PS, adequate organ function and longer expected survival $(\geq 3$ months). In this scenario, recent advances in genomic profiling have the potential to open a new era in BTC management, moving towards a personalized approach based on specific molecular aberrations (153). For the reasons mentioned above, in BTC patients whose disease has progressed after front-line treatment, careful consideration should be given to genomic testing and enrolment in biomarker-driven clinical trials assessing novel targeted agents and combinations.

\section{Conclusion}

Identification of effective and well-tolerated second-line treatment regimens for previously treated BTC patients is urgently needed. Despite notable advancements in the comprehension of the BTC molecular landscape, many questions are yet to be answered. To date, precision medicine in BTC is limited to iCCA and has mainly focused on agents targeting IDH and FGFR. The detection of the subset of patients which might benefit from second-line treatment, the choice of the optimal regimen and the effects of treatment on quality of life remain mandatory elements in choosing the best therapeutic strategy in this setting.

\section{Conflicts of Interest}

The Authors state that they have no conflicts of interest in regard to this study.

\section{Authors' Contributions}

AR, ADR: concept, design, review of literature and final review; NT, MCN, MM: concept, design, review of literature; AP, FA, GF, SDL: final review and approval; ST, GB: concept, design, final review and approval.

\section{Acknowledgements}

The Authors received no financial support for the research, authorship, or publication of this article. 


\section{References}

1 Adeva J, Sangro B, Salati M, Edeline J, La Casta A, Bittoni A, Berardi R, Bruix $\mathrm{J}$ and Valle JW; Medical treatment for cholangiocarcinoma. Liver Int 39(Suppl 1): 123-142, 2019. PMID: 30892822. DOI: 10.1111/liv.14100

2 De Lorenzo S, Tovoli F, Barbera MA, Garuti F, Palloni A, Frega G, Garajova I, Rizzo A, Trevisani F and Brandi G: Metronomic capecitabine vs. best supportive care in Child-Pugh B hepatocellular carcinoma: a proof of concept. Sci Rep 8(1): 9997, 2018. PMID: 29968763. DOI: 10.1038/s41598-018-28337-6

3 Khan SA, Tavolari S and Brandi G: Cholangiocarcinoma: Epidemiology and risk factors. Liver Int 39(Suppl 1): 19-31, 2019. PMID: 30851228. DOI: 10.1111/liv.14095

4 Rizvi S and Gores GJ: Pathogenesis, diagnosis, and management of cholangiocarcinoma. Gastroenterology 145(6): 1215-1229, 2013. PMID: 24140396. DOI: 10.1053/j.gastro.2013.10.013

5 Razumilava N and Gores GJ: Cholangiocarcinoma. Lancet 383(9935): 2168-2179, 2014. PMID: 24581682. DOI: 10.1016/S0140-6736(13)61903-0.

6 Patel $\mathrm{T}$ : Worldwide trends in mortality from biliary tract malignancies. BMC Cancer 2: 10, 2002. PMID: 11991810. DOI: 10.1186/1471-2407-2-10

7 Saha SK, Zhu AX, Fuchs CS and Brooks GA: Forty-year trends in cholangiocarcinoma incidence in the US: intrahepatic disease on the rise. Oncologist 21: 594-599, 2016. PMID: 27000463. DOI: 10.1634/theoncologist.2015-0446

8 Forner A, Vidili G, Rengo M, Bujanda L, Ponz-Sarvisé M and Lamarca A: Clinical presentation, diagnosis and staging of cholangiocarcinoma. Liver Int 39(Suppl 1): 98-107, 2019. PMID: 30831002. DOI: 10.1111/liv.14086

9 Rizvi S, Khan SA, Hallemeier CL, Kelley RK and Gores GJ: Cholangiocarcinoma - evolving concepts and therapeutic strategies. Nat Rev Clin Oncol 15(2): 95-111, 2018. PMID: 28994423. DOI: 10.1038/nrclinonc.2017.157

10 Valle J, Wasan H, Palmer DH, Cunningham D, Anthoney A, Maraveyas A, Madhusudan S, Iveson T, Hughes S, Pereira SP, Roughton $\mathrm{M}$ and Bridgewater $\mathrm{J}$; ABC-02 Trial Investigators: Cisplatin plus gemcitabine versus gemcitabine for biliary tract cancer. N Engl J Med 362: 1273-1281, 2010. PMID: 20375404. DOI: $10.1056 /$ NEJMoa0908721

11 Brandi G, Rizzo A, Dall'Olio FG, Felicani C, Ercolani G, Cescon M, Frega G, Tavolari S, Palloni A, De Lorenzo S, Abbati F, Mollica V, Ricci AD and Serra C: Percutaneous radiofrequency ablation in intrahepatic cholangiocarcinoma: a retrospective single-center experience. Int J Hyperthermia 37: 479-485, 2020. DOI: $10.1080 / 02656736.2020 .1763484$

12 Brandi G, Farioli A, Astolfi A, Biasco G and Tavolari S: Genetic heterogeneity in cholangiocarcinoma: a major challenge for targeted therapies. Oncotarget 6(17): 14744-14753, 2015. PMID: 26142706. DOI: 10.18632 oncotarget.4539

13 Fornaro L, Cereda S, Aprile G, Di Girolamo S, Santini D, Silvestris N, Lonardi S, Leone F, Milella M, Vivaldi C, Belli C, Bergamo F, Lutrino SE, Filippi R, Russano M, Vaccaro V, Brunetti AE, Rotella V, Falcone A, Barbera MA, Corbelli J, Fasola G, Aglietta M, Zagonel V, Reni M, Vasile E and Brandi G: Multivariate prognostic factors analysis for second-line chemotherapy in advanced biliary tract cancer. Br J Cancer 110(9): 2165-2169, 2014. PMID: 24714745. DOI: 10.1038/bjc. 2014.190
14 Banales JM, Cardinale V, Carpino G, Marzioni M, Andersen JB, Invernizzi P, Lind GE, Folseraas T, Forbes SJ, Fouassier L, Geier A, Calvisi DF, Mertens JC, Trauner M, Benedetti A, Maroni L, Vaquero J, Macias RI, Raggi C, Perugorria MJ, Gaudio E, Boberg KM, Marin JJ and Alvaro D: Expert consensus document: Cholangiocarcinoma: current knowledge and future perspectives consensus statement from the European Network for the Study of Cholangiocarcinoma (ENS-CCA). Nat Rev Gastroenterol Hepatol 13(5): 261-280, 2016. PMID: 27095655. DOI: 10.1038/nrgastro. 2016.51

15 Robertson S, Hyder O, Dodson R, Nayar SK, Poling J, Beierl K, Eshleman JR, Lin MT, Pawlik TM and Anders RA: The frequency of KRAS and BRAF mutations in intrahepatic cholangiocarcinomas and their correlation with clinical outcome. Hum Pathol 44(12): 2768-2773, 2013. PMID: 24139215. DOI: 10.1016/j.humpath.2013.07.026

16 Voss JS, Holtegaard LM, Kerr SE, Fritcher EG, Roberts LR, Gores GJ, Zhang J, Highsmith WE, Halling KC and Kipp BR: Molecular profiling of cholangiocarcinoma shows potential for targeted therapy treatment decisions. Hum Pathol 44(7): 1216-1222, 2013. PMID: 23391413. DOI: 10.1016/j.humpath.2012.11.006

17 Santoni M, Massari F, Del Re M, Ciccarese C, Piva F, Principato G, Montironi R, Santini D, Danesi R, Tortora G and Cascinu S: Investigational therapies targeting signal transducer and activator of transcription 3 for the treatment of cancer. Expert Opin Investig Drugs 24(6): 809-824, 2015. PMID: 25746129. DOI: 10.1517/ 13543784.2015.1020370

18 Bridgewater JA, Goodman KA, Kalyan A and Mulcahy MF: Biliary tract cancer: epidemiology, radiotherapy, and molecular profiling. Am Soc Clin Oncol Educ Book 35: e194-203, 2016. PMID: 27249723. DOI: 10.14694/EDBK_160831

19 Mollica V, Di Nunno V, Gatto L, Santoni M, Cimadamore A, Cheng L, Lopez-Beltran A, Montironi R, Pisconti S, Battelli N and Massari F: Novel therapeutic approaches and targets currently under evaluation for renal cell carcinoma: waiting for the revolution. Clin Drug Invest 39(6): 503-519, 2019. PMID: 30937824. DOI: 10.1007/s40261-019-00773-w

20 Modena A, Ciccarese C, Iacovelli R, Brunelli M, Montironi R, Fiorentino $\mathrm{M}$, Tortora $\mathrm{G}$ and Massari F: Immune checkpoint inhibitors and prostate cancer: a new frontier? Oncol Rev 10(1): 293, 2016. PMID: 27471580. DOI: 10.4081/oncol.2016.293

21 Parry RV, Chemnitz JM, Frauwirth KA, Lanfranco AR, Braunstein I, Kobayashi SV, Linsley PS, Thompson CB and Riley JL: CTLA- 4 and PD-1 receptors inhibit T-cell activation by distinct mechanisms. Mol Cell Biol 25: 95439553, 2005. PMID: 16227604. DOI: 10.1128/MCB.25. 21.9543-9553.2005

22 Weber JS, Hodi FS, Wolchok JD, Topalian SL, Schadendorf D, Larkin J, Sznol M, Long GV, Li H, Waxman IM, Jiang J and Robert C: Safety profile of nivolumab monotherapy: a pooled analysis of patients with advanced melanoma. J Clin Oncol 35(7): 785-792, 2017. PMID: 28068177. DOI: 10.1200/JCO.2015. 66.1389

23 Keating GM: Nivolumab: A review in advanced nonsquamous non-small cell lung cancer. Drugs 76(9): 969-978, 2016. PMID: 27189706. DOI: 10.1007/s40265-016-0589-9

24 Morizane C, Ueno M, Ikeda M, Okusaka T, Ishii H and Furuse J: New developments in systemic therapy for advanced biliary tract cancer. Jpn J Clin Oncol 48(8): 703-711, 2018. PMID: 29893894. DOI: $10.1093 /$ jjco/hyy082 
25 Brandi $G$ and Tavolari S: Asbestos and intrahepatic cholangiocarcinoma. Cells 9(2), 2020. PMID: 32059499. DOI: 10.3390/cells 9020421

26 Sasaki T, Isayama H, Yashima Y, Yagioka H, Kogure H, Arizumi T, Togawa O, Matsubara S, Ito Y, Nakai Y, Sasahira N, Hirano K, Tsujino T, Tada M, Kawabe T and Omata M: S-1 Monotherapy in patients with advanced biliary tract cancer. Oncology 77(1): 7174, 2009. PMID: 19556812. DOI: 10.1159/000226214

27 Sasaki T, Isayama H, Nakai Y, Mizuno S, Yamamoto K, Yagioka H, Yashima Y, Kawakubo K, Kogure H, Togawa O, Matsubara S, Ito Y, Sasahira N, Hirano K, Tsujino T, Toda N, Tada M, Omata $\mathrm{M}$ and Koike K: Multicenter phase II study of S-1 monotherapy as second-line chemotherapy for advanced biliary tract cancer refractory to gemcitabine. Invest New Drugs 30(2): 708-713, 2012. PMID: 20924641. DOI: 10.1007/s10637-010-9553-9

28 Suzuki E, Ikeda M, Okusaka T, Nakamori S, Ohkawa S, Nagakawa T, Boku N, Yanagimoto H, Sato T and Furuse J: A multicenter phase II study of S-1 for gemcitabine-refractory biliary tract cancer. Cancer Chemother Pharmacol 71(5): 11411146, 2013. PMID: 23525694. DOI: 10.1007/s00280-013-21060

29 Sebbagh S, Roux J, Dreyer C, Neuzillet C, de Gramont A, Orbegoso C, Hentic O, Hammel P, de Gramont A, Raymond E, André T, Chibaudel B and Faivre S: Efficacy of a sequential treatment strategy with GEMOX-based followed by FOLFIRIbased chemotherapy in advanced biliary tract cancers. Acta Oncol (Madr) 55(9-10): 1168-1174, 2016. PMID: 27333436. DOI: 10.1080/0284186X.2016.1191670

30 Dodagoudar C, Doval DC, Mahanta A, Goel V, Upadhyay A, Goyal P, Talwar V, Singh S, John MC, Tiwari S and Patnaik N: FOLFOX-4 as second-line therapy after failure of gemcitabine and platinum combination in advanced gall bladder cancer patients. Jpn J Clin Oncol 46(1): 57-62, 2016. PMID: 26603355. DOI: $10.1093 /$ jjco/hyv148

31 Hwang IG, Jang J-S, Oh SY, Rho MH, Lee S, Park YS, Park JO, Nam EM, Lee HR, Jun HJ and Chi KC: Phase II study of mFOLFOX3 (5-fluorouracil, leucovorin, oxaliplatin) as secondline treatment after gemcitabine failure in patients with unresectable/metastatic biliary tract cancer. Cancer Chemother Pharmacol 75(4): 757-762, 2015. PMID: 25677446. DOI: 10.1007/s00280-015-2691-1

32 Lamarca A, Hubner RA, David Ryder W and Valle JW: Secondline chemotherapy in advanced biliary cancer: A systematic review. Ann Oncol 25(12): 2328-2338, 2014. PMID: 24769639. DOI: $10.1093 /$ annonc/mdu162

33 Ying $\mathrm{J}$ and Chen J: Combination versus mono-therapy as salvage treatment for advanced biliary tract cancer: A comprehensive meta-analysis of published data. Crit Rev Oncol Hematol 139(68): 134-142, 2019. PMID: 30979533. DOI: 10.1016/j.critrevonc. 2019.01.001

34 Lamarca A: ABC-06. A randomised phase III, multi-centre, openlabel study of active symptom control (ASC) alone or ASC with oxaliplatin/5-FU chemotherapy (ASC+mFOLFOX) for patients (pts) with locally advanced/metastatic biliary tract cancers (ABC) previously-tr. J Clin Oncol 37: abstr 4003, 2019. DOI: 10.1200/JCO.2019.37.15_suppl.4003

35 Belkouz A, de Vos-Geelen J, Mathot RAA, Eskens FALM, van Gulik TM, van Oijen MGH, Punt CJA, Wilmink JW and Klümpen HJ: Efficacy and safety of FOLFIRINOX as salvage treatment in advanced biliary tract cancer: an open-label, single arm, phase 2 trial. Br J Cancer 122(5): 634-639, 2020. PMID: 31919404. DOI: 10.1038/s41416-019-0698-9

36 Katoh $\mathrm{M}$ and Nakagama H: FGF receptors: cancer biology and therapeutics. Med Res Rev 34(2): 280-300, 2014. PMID: 23696246. DOI: 10.1002/med.21288

37 Krook MA, Lenyo A, Wilberding M, Barker H, Dantuono M, Bailey KM, Chen HZ, Reeser JW, Wing MR, Miya J, Samorodnitsky E, Smith AM, Dao T, Martin DM, Ciombor KK, Hays J, Freud AG and Roychowdhury S: Efficacy of FGFR inhibitors and combination therapies for acquired resistance in FGFR2-fusion cholangiocarcinoma. Mol Cancer Ther 19(3): 847857, 2020. PMID: 31911531. DOI: 10.1158/1535-7163.MCT-190631

38 Arai Y, Totoki Y, Hosoda F, Shirota T, Hama N, Nakamura H, Ojima H, Furuta K, Shimada K, Okusaka T, Kosuge T and Shibata T: Fibroblast growth factor receptor 2 tyrosine kinase fusions define a unique molecular subtype of cholangiocarcinoma. Hepatology 59(4): 1427-1434, 2014. PMID: 24122810. DOI: 10.1002/hep.26890

39 Graham RP, Barr Fritcher EG, Pestova E, Schulz J, Sitailo LA, Vasmatzis G, Murphy SJ, McWilliams RR, Hart SN, Halling KC, Roberts LR, Gores GJ, Couch FJ, Zhang L, Borad MJ and Kipp BR: Fibroblast growth factor receptor 2 translocations in intrahepatic cholangiocarcinoma. Hum Pathol 45: 1630-1638, 2014. PMID: 24837095. DOI: 10.1016/j.humpath.2014.03.014

40 Javle M, Lowery M, Shroff RT, Weiss KH, Springfeld C, Borad MJ, Ramanathan RK, Goyal L, Sadeghi S, Macarulla T, ElKhoueiry A, Kelley RK, Borbath I, Choo SP, Oh DY, Philip PA, Chen LT, Reungwetwattana T, Van Cutsem E, Yeh KH, Ciombor K, Finn RS, Patel A, Sen S, Porter D, Isaacs R, Zhu AX, AbouAlfa GK and Bekaii-Saab T: Phase II study of BGJ398 in patients with FGFR-altered advanced cholangiocarcinoma. J Clin Oncol 36: 276-282, 2018. PMID: 29182496. DOI: 10.1200/JCO.2017. 75.5009

41 Mazzaferro V, El-Rayes BF, Droz Dit Busset M, Cotsoglou C, Harris WP, Damjanov N, Masi G, Rimassa L, Personeni N, Braiteh F, Zagonel V, Papadopoulos KP, Hall T, Wang Y, Schwartz B, Kazakin J, Bhoori S, de Braud F and Shaib WL: Derazantinib (ARQ 087) in advanced or inoperable FGFR2 gene fusion-positive intrahepatic cholangiocarcinoma. Br J Cancer 120: 165-171, 2019. PMID: 30420614. DOI: 10.1038/s41416-0180334-0

42 Bahleda R, Italiano A, Hierro C, Mita A, Cervantes A, Chan N, Awad M, Calvo E, Moreno V, Govindan R, Spira A, Gonzalez M, Zhong B, Santiago-Walker A, Poggesi I, Parekh T, Xie H, Infante $\mathrm{J}$ and Tabernero J: Multicenter phase 1 study of erdafitinib (JNJ42756493), oral pan-fibroblast growth factor receptor inhibitor, in patients with advanced or refractory solid tumor. Clin Cancer Res 25: 4999-4897, 2019. PMID: 31088831. DOI: 10.1158/10780432.CCR-18-3334

43 Abou-Alfa GK, Sahai V, Hollebecque A, Vaccaro G, Melisi D, Al-Rajabi R, Paulson AS, Borad MJ, Gallinson D, Murphy AG, Oh DY, Dotan E, Catenacci DV, Van Cutsem E, Ji T, Lihou CF, Zhen H, Féliz L and Vogel A: Pemigatinib for previously treated, locally advanced or metastatic cholangiocarcinoma: A multicentre, open-label, phase 2 study. Lancet Oncol pii: S14702045(20)30109-1, 2020. PMID: 32203698. DOI: 10.1016/S14702045(20)30109-1

44 Goyal L, Shi L, Liu LY, Fece de la Cruz F, Lennerz JK, Raghavan S, Leschiner I, Elagina L, Siravegna G, Ng RWS, Vu P, Patra KC, 
Saha SK, Uppot RN, Arellano R, Reyes S, Sagara T, Otsuki S, Nadres B, Shahzade HA, Dey-Guha I, Fetter IJ, Baiev I, Van Seventer EE, Murphy JE, Ferrone CR, Tanabe KK, Deshpande V, Harding JJ, Yaeger R, Kelley RK, Bardelli A, Iafrate AJ, Hahn WC, Benes CH, Ting DT, Hirai H, Getz G, Juric D, Zhu AX, Corcoran RB and Bardeesy N: TAS- 120 overcomes resistance to ATP-competitive FGFR inhibitors in patients with FGFR2 fusionpositive intrahepatic cholangiocarcinoma. Cancer Discov 9(8): 1064-1079, 2019. PMID: 31109923. DOI: 10.1158/21598290.CD-19-0182

45 Krook MA, Lenyo A, Wilberding M, Barker H, Dantuono M, Bailey KM, Chen HZ, Reeser JW, Wing MR, Miya J, Samorodnitsky E, Smith AM, Dao T, Martin DM, Ciombor KK, Hays J, Freud AG and Roychowdhury S: Efficacy of FGFR inhibitors and combination therapies for acquired resistance in FGFR2-Fusion cholangiocarcinoma. Mol Cancer Ther 19(3): 847857, 2020. PMID: 31911531. DOI: 10.1158/1535-7163.MCT-190631

46 Zhao DY and Lim KH: Current biologics for treatment of biliary tract cancer. J Gastrointest Oncol 8(3): 430-440, 2017. PMID: 28736630. DOI: 10.21037/jgo.2017.05.04

47 Borger DR, Tanabe KK, Fan KC, Lopez HU, Fantin VR, Straley KS, Schenkein DP, Hezel AF, Ancukiewicz M, Liebman HM, Kwak EL, Clark JW, Ryan DP, Deshpande V, Dias-Santagata D, Ellisen LW, Zhu AX and Iafrate AJ: Frequent mutation of isocitrate dehydrogenase (IDH) 1 and IDH2 in cholangiocarcinoma identified through broad-based tumor genotyping. Oncologist 17(1): 72-79, 2012. PMID: 22180306. DOI: 10.1634/theoncologist.2011-0386

48 Qian MB, Utzinger J, Keiser J and Zhou XN: Clonorchiasis. Lancet 387(10020): 800-810, 2016. PMID: 26299184. DOI: 10.1016/S0140-6736(15)60313-0

49 Saha SK, Gordan JD, Kleinstiver BP, Vu P, Najem MS, Yeo JC, Shi L, Kato Y, Levin RS, Webber JT, Damon LJ, Egan RK, Greninger P, McDermott U, Garnett MJ, Jenkins RL, RiegerChrist KM, Sullivan TB, Hezel AF, Liss AS, Mizukami Y, Goyal L, Ferrone CR, Zhu AX, Joung JK, Shokat KM, Benes CH and Bardeesy N: Isocitrate dehydrogenase mutations confer dasatinib hypersensitivity and SRC-dependence in intrahepatic cholangiocarcinoma. Cancer Discov 6(7): 727-739, 2016. PMID: 27231123. DOI: $10.1158 / 2159-8290 . C D-15-1442$

50 Lampis A, Carotenuto P, Vlachogiannis G, Cascione L, Hedayat S, Burke R, Clarke P, Bosma E, Simbolo M, Scarpa A, Yu S, Cole R, Smyth E, Mateos JF, Begum R, Hezelova B, Eltahir Z, Wotherspoon A, Fotiadis N, Bali MA, Nepal C, Khan K, Stubbs M, Hahne JC, Gasparini P, Guzzardo V, Croce CM, Eccles S, Fassan M, Cunningham D, Andersen JB, Workman P, Valeri N and Braconi C: MIR21 drives resistance to heat shock protein 90 inhibition in cholangiocarcinoma. Gastroenterology 154(4): 10661079, 2018. PMID: 29113809. DOI: 10.1053/j.gastro.2017.10.043

51 Lowery MA, Burris HA, III, Janku F, Shroff RT, Cleary JM, Azad NS, Goyal L, Maher EA, Gore L, Hollebecque A, Beeram M, Trent JC, Jiang L, Fan B, Aguado-Fraile E, Choe S, Wu B, Gliser C, Agresta SV, Pandya SS, Zhu AX and Abou-Alfa GK: Safety and activity of ivosidenib in patients with IDH1-mutant advanced cholangiocarcinoma: a phase 1 study. Lancet Gastroenterol Hepatol 4: 711-720, 2019. PMID: 31300360. DOI: 10.1016/S24 68-1253(19)30189-X

52 Abou-Alfa GK, Macarulla Mercade T, Javle M, Kelley RK, Lubner S, Adeva J, Cleary JM, Catenacci DV, Borad MJ,
Bridgewater JA, Harris WP, Murphy AG, Oh D-Y, Whisenant J, Wu B, Jiang L, Gliser C, Pandya SS, Valle JW and Zhu AW: LBA10_PRClarIDHy: A global, phase III, randomized, doubleblind study of ivosidenib (IVO) vs placebo in patients with advanced cholangiocarcinoma (CC) with an isocitrate dehydrogenase 1 (IDH1) mutation. Ann Oncol 30(5), 2019. DOI: 10.1093/annonc/mdz394.027

53 Sulkowski PL, Corso CD, Robinson ND, Scanlon SE, Purshouse KR, Bai H, Liu Y, Sundaram RK, Hegan DC, Fons NR, Breuer GA, Song Y, Mishra-Gorur K, De Feyter HM, de Graaf RA, Surovtseva YV, Kachman M, Halene S, Günel M, Glazer PM and Bindra RS: 2-Hydroxyglutarate produced by neomorphic IDH mutations suppresses homologous recombination and induces PARP inhibitor sensitivity. Sci tranl Med 9(375): eaal2463, 2017. PMID: 28148839. DOI: 10.1126/scitranslmed.aal2463

54 Pignochino Y, Sarotto I, Peraldo- Neia C, Penachioni JY, Cavalloni G, Migliardi G, Casorzo L, Chiorino G, Risio M, Bardelli A, Aglietta M and Leone F: Targeting EGFR/HER2 pathways enhances the antiproliferative effect of gem- citabine in biliary tract and gallbladder carcinomas. BMC 10: 631, 2010. PMID: 21087480. DOI: 10.1186/1471-2407-10-631

55 Rizzo A, Frega G, Ricci AD, Palloni A, Abbati F, DE Lorenzo S, Deserti M, Tavolari S and Brandi G: Anti-EGFR monoclonal antibodies in advanced biliary tract cancer: a systematic review and meta-analysis. In Vivo 34(2): 479-488, 2020. PMID: 32111744. DOI: 10.21873/invivo. 11798

56 Jensen LH, Lindebjerg J, Ploen J, Hansen TF and Jakobsen A: Phase II marker-driven trial of panitumumab and chemotherapy in KRAS wild-type biliary tract cancer. Ann Oncol 23(9): 23412346, 2012. PMID: 22367707. DOI: 10.1093/annonc/mds008

57 Philip PA, Mahoney MR, Allmer C, Thomas J, Pitot HC, Kim G, Donehower RC, Fitch T, Picus J and Erlichman C: Phase II study of erlotinib in patients with advanced biliary cancer. J Clin Oncol 24(19): 3069-3074, 2006. PMID: 16809731.

58 Lee J, Park SH, Chang HM, Kim JS, Choi HJ, Lee MA, Jang JS, Jeung HC, Kang JH, Lee HW, Shin DB, Kang HJ, Sun JM, Park JO, Park YS, Kang WK and Lim HY: Gemcitabine and oxaliplatin with or without erlotinib in advanced biliary-tract cancer: a multicentre, open-label, randomised, phase 3 study. Lancet Oncol 13(2): 181-188, 2012. PMID: 22192731. DOI: 10.1016/S1470-2045(11)70301-1

59 El-Khoueiry AB, Rankin C, Siegel AB, Iqbal S, Gong IY, Micetich KC, Kayaleh OR, Lenz HJ and Blanke CD: SO941: a phase 2 SWOG study of sorafenib and erlotinib in patients with advanced gallbladder carcinoma or cholangiocarcinoma. Br J Cancer 110(4): 882-887, 2014. PMID: 24423918. DOI: 10.1038/ bjc. 2013.801

60 Chiorean EG, Ramasubbaiah R, Yu M, Picus J, Bufill JA, Tong Y, Coleman N, Johnston EL, Currie C and Loehrer PJ: Phase II trial of erlotinib and docetaxel in advanced and refractory hepatocellular and biliary cancers: Hoosier Oncology Group GI06-101. Oncologist 17(1): 13, 2012. PMID: 22210086. DOI: 10.1634/theoncologist.2011-0253

61 Rubovszky G, Láng I, Ganofszky E, Horváth Z, Juhos E, Nagy T, Szabó E, Szentirmay Z, Budai B and Hitre E: Cetuximab, gemcitabine and capecitabine in patients with inoperable biliary tract cancer: a phase 2 study. Eur J Cancer 49(18): 3806-3812, 2013. PMID: 24007821. DOI: 10.1016/j.ejca.2013.07.143

62 Sohal DPS, Mykulowycz K, Uehara T, Teitelbaum UR, Damjanov $\mathrm{N}$, Giantonio BJ, Carberry M, Wissel P, Jacobs-Small M, 
O'Dwyer PJ, Sepulveda A and Sun W: A phase II trial of gemcitabine, irinotecan and panitumumab in advanced cholangiocarcinoma. Ann Oncol 24(12): 3061-3065, 2013. PMID: 24146220. DOI: $10.1093 /$ annonc/mdt416

63 Ciombor KK and Goff LW: Advances in the management of biliary tract cancers. Clin Adv Hematol Oncol 11(1): 28-34, 2013. PMID: 23416860.

64 Pellat A, Vaquero J and Fouassier L: Role of ErbB/HER family of receptor tyrosine kinases in cholangiocyte biology. Hepatology 67(2): 762-773, 2018. PMID: 28671339. DOI: 10.1002/hep29350.

65 Oh DY and Bang YJ: HER2-targeted therapies - a role beyond breast cancer. Nat Rev Clin Oncol 17(1): 33-48, 2020. PMID: 31548601. DOI: 10.1038/s41571-019-0268-3

66 Mishra SK, Kumari N and Krishnani N: Molecular pathogenesis of gallbladder cancer: An update. Mutat Res 816-818: 111674, 2019. PMID: 31330366 . DOI: 10.1016/j.mrfmmm.2019.111674

67 Guo Y, Feng K, Liu Y, Wu Z, Dai H, Yang Q, Wang Y, Jia H and Han W: Phase I study of chimeric antigen receptor-modified T cells in patients with EGFR-positive advanced biliary tract cancers. Clin Cancer Res 24(6): 1277-1286, 2018. PMID: 29138340. DOI: 10.1158/1078-0432.CCR-17-0432

68 Yarden Y and Sliwkowski MX: Untangling the ErbB signalling network. Nat Rev Mol Cell Biol 2: 127-137, 2001. PMID: 11252954. DOI: $10.1038 / 35052073$

69 Lamarca A, Galdy S, Barriuso J, Moghadam S, Beckett E, Rogan J, Backen A, Billington C, McNamara MG, Hubner RA, Cramer A and Valle JW: The HER3 pathway as a potential target for inhibition in patients with biliary tract cancers. PLoS One 13: e0206007, 2018. PMID: 30335866. DOI: 10.1371/journal.pone. 0206007

70 Javle M, Bekaii-Saab T, Jain A, Kelley RK, Wang K, Kang HC, Catenacci D, Ali S, Krishnan S, Ahn D, Bocobo AG, Zuo M, Kaseb A, Miller V, Stephens PJ, Meric-Bernstam F, Shroff R and Ross J: Biliary cancer: Utility of next-generation sequencing for clinical management. Cancer 122: 3838-3847, 2016. PMID: 27622582. DOI: $10.1002 /$ cncr.30254

71 Javle M, Churi C, Kang HC, Shroff R, Janku F, Surapaneni R, Zuo M, Barrera C, Alshamsi H, Krishnan S, Mishra L, Wolff RA, Kaseb AO, Thomas MB and Siegel AB: HER2/neu-directed therapy for biliary tract cancer. J Hematol Oncol 8: 58, 2015. PMID: 26022204. DOI: 10.1186/s13045-015-0155-z

72 Boku N: HER2-positive gastric cancer. Gastric Cancer 17(1): 112, 2014. PMID: 23563986. DOI: 10.1007/s10120-013-0252-z

73 Rizzo A, Mollica V, Ricci AD, Maggio I, Massucci M, Rojas Limpe FL, Fabio FD and Ardizzoni A: Third- and later-line treatment in advanced or metastatic gastric cancer: a systematic review and meta-analysis. Future Oncol 16(2): 4409-4418, 2020. PMID: 31793342. DOI: 10.2217/fon-2019-0429

74 Javle MM, Hainsworth JD, Swanton C, Burris HA, Kurzrock R, Sweeney C, Meric-Bernstam F, Spigel DR, Bose R, Guo S, Bernaards C, Beattie MS, Scappaticci FA and Hurwitx H: Pertuzumab + trastuzumab for HER2-positive metastatic biliary cancer: Preliminary data from MyPathway. J Clin Oncol 35: 402, 2019. DOI: 10.1200/JCO.2017.35.4_suppl.402

75 Hyman DM, Piha-Paul SA, Won H, Rodon J, Saura C, Shapiro GI, Juric D, Quinn DI, Moreno V, Doger B, Mayer IA, Boni V, Calvo E, Loi S, Lockhart AC, Erinjeri JP, Scaltriti M, Ulaner GA, Patel J, Tang J, Beer H, Selcuklu SD, Hanrahan AJ, Bouvier N, Melcer M, Murali R, Schram AM, Smyth LM, Jhaveri K, Li BT,
Drilon A, Harding JJ, Iyer G, Taylor BS, Berger MF, Cutler RE Jr., Xu F, Butturini A, Eli LD, Mann G, Farrell C, Lalani AS, Bryce RP, Arteaga CL, Meric-Bernstam F, Baselga J and Solit DB: HER kinase inhibition in patients with HER2- and HER3mutant cancers. Nature 554: 189-194, 2018. PMID: 29420467. DOI: $10.1038 /$ nature25475

76 Harding J, Cleary J, Shapiro G, Braña I, Moreno V, Quinn D, Borad M, Loi S, Spangaard I, Stemmer S, Dujka M, Cutler R, Xu F, Eli L, Macia S,M Lalani A, Bryce R, Meric-Bernstam F, Solit D, Hyman D and Piha-Paul S: Treating HER2- mutant advanced biliary tract cancer with neratinib: benefits of HER2-directed targeted therapy in the phase 2 SUMMIT 'basket' trial. ESMO World Congress on GI Cancer 2019, abstract O-005, 2019. DOI: 10.1093/annonc/mdz154.004

77 Tan AC, Oh DY, Chao Y, Hsieh CY, Chang WL, Isanto F, Chen YC, McHale M, Lindmark B and $\mathrm{Ng} \mathrm{MCH}$ : Efficacy and safety of varlitinib, a reversible pan-HER tyrosine kinase inhibitor, in combination with platinum-based regimens in biliary tract cancers: a pooled analysis from three phase 1 studies. J Clin Oncol 37: 331, 2019. DOI: 10.1200/ JCO.2019.37.4_suppl.331

78 Ramanathan RK, Belani CP, Singh DA, Tanaka M, Lenz HJ, Yen Y, Kindler HL, Iqbal S, Longmate J, Mack PC, Lurje G, GandourEdwards R, Dancey J and Gandara DR: A phase II study of lapatinib in patients with advanced biliary tree and hepatocellular cancer. Cancer Chemother Pharmacol 64: 777-783, 2009. PMID: 19169683. DOI: 10.1007/s00280-009-0927-7

79 Moehler M, Maderer A, Ehrlich A, Foerster F, Schad A, Nickolay T, Ruckes C, Weinmann A, Sivanathan V, Marquardt JU, Galle PR, Woerns M and Thomaidis T: Safety and efficacy of afatinib as add-on to standard therapy of gemcitabine/cisplatin in chemotherapy-naive patients with advanced biliary tract cancer: an open-label, phase I trial with an extensive biomarker program. BMC Cancer 19: 55, 2019. PMID: 30634942. DOI: 10.1186/ s12885-018-5223-7

80 Simone V, Brunetti O, Lupo L, Testini M, Maiorano E, Simone M, Longo V, Rolfo C, Peeters M, Scarpa A, Azzariti A, Russo A, Ribatti D and Silvestris N: Targeting angiogenesis in biliary tract cancers: An open option. Int J Mol Sci 18: 418, 2017. PMID: 28212293. DOI: $10.3390 /$ ijms 18020418

81 Kudo M, Galle PR, Llovet JM, Finn RS, Vogel A, Motomura K, Assenat E, Merle P, Brandi G, Daniele B, Okusaka T, Tomášek J, Borg C, Dadduzio V, Morimoto M, Pracht M, Jen MH, Ubreva ND, Widau RC, Shinozaki K, Yoshikawa R and Zhu AX: Ramucirumab in elderly -patients with hepatocellular carcinoma and elevated alpha-fetoprotein after sorafenib in REACH and REACH-2. Liver Int 12, 2020. PMID: 32279446. DOI: 10.1111/liv.14462

82 Leyva-Illades D, McMillin M, Quinn $\mathrm{M}$ and Demorrow S: Cholangiocarcinoma pathogenesis: role of the tumor microenvironment. Transl Gastrointest Cancer 1(1): 71, 2012. PMID: 23002431

83 Moeini A, Sia D, Bardeesy N, Mazzaferro V and Llovet JM: Molecular pathogenesis and targeted therapies for intrahepatic cholangiocarcinoma. Clin Cancer Res 22: 291-300, 2015. PMID: 26405193. DOI: 10.1158/1078-0432.CCR-14-3296

84 Kawahara N, Ono M, Taguchi K, Okamoto M, Shimada M, Takenaka K, H: ayashi K, Mosher DF, Sugimachi K, Tsuneyoshi $\mathrm{M}$ and Kuwano M: Enhanced expression of thrombospondin-1 and hypovascularity in human cholangiocarcinoma. Hepatology 
28(6): 1512-1517, 1998. PMID: 9828214. DOI: 10.1002/ hep. 510280610

85 Larsen FO, Markussen A, Diness LV and Nielsen D: Efficacy and safety of capecitabine, irinotecan, gemcitabine, and bevacizumab as second-line treatment in advanced biliary tract cancer: A phase II study. Oncology 94(1): 19-24, 2018. PMID: 28930749. DOI: $10.1159 / 000479970$

86 Santoni M, Buti S, Conti A, Porta C, Procopio G, Sternberg CN, Bracarda S, Basso U, De Giorgi U, Rizzo M, Derosa L, Ortega C, Massari F, Milella M, Bersanelli M, Cerbone L, Muzzonigro G, Burattini L, Montironi R, Santini D and Cascinu S: Prognostic significance of host immune status in patients with late relapsing renal cell carcinoma treated with targeted therapy. Target Oncol 10(4): 517-522, 2015. PMID: 25559290. DOI: 10.1007/s11523014-0356-3

87 Neuzillet C, Seitz JF, Fartoux L, Malka D, Lledo G, TijerasRaballand A, De Gramont A, Ronot M, Bouattour M, Dreyer C, Amin A, Brunisholz-Bourget $\mathrm{P}$, Hadengue A, Roldan N, Chibaudel B, Raymond E and Faivre SJ: Sunitinib as second-line treatment in patients with advanced intrahepatic cholangiocarcinoma (SUN-CK phase II trial): Safety, efficacy, and updated translational results. J Clin Oncol 33(3_suppl): 343, 2015. DOI: 10.1200/jco.2015.33.3_suppl.343

88 Ikeda M, Sasaki T, Morizane C, Mizuno N, Nagashima F, Shimuzu S, Hayata N, Ikezawa H, Suzuki T, Nakajima R, Ductus $\mathrm{C}$ and Ueno M: A phase 2 study of Lenvatinib monotherapy as second-line treatment in unresectable biliary tract cancer: primary analysis results. Ann Oncol 28 (suppl_5): v209-v268, 2017. DOI: 10.1093/annonc/mdx369

89 Zhu AX, Kang YK, Yen CJ, Finn RS, Galle PR, Llovet JM, Assenat E, Brandi G, Pracht M, Lim HY, Rau KM, Motomura K, Ohno I, Merle P, Daniele B, Shin DB, Gerken G, Borg C, Hiriart JB, Okusaka T, Morimoto M, Hsu Y, Abada PB and Kudo M; REACH-2 study investigators: Ramucirumab after sorafenib in patients with advanced hepatocellular carcinoma and increased $\alpha$ fetoprotein concentrations (REACH-2): a randomised, doubleblind, placebo-controlled, phase 3 trial. Lancet Oncol 20(2): 282296, 2019. PMID: 30665869. DOI: 10.1016/S1470-2045(18) 30937-9

90 Arkenau HT, Martin-Liberal J, Calvo E, Penel N, Krebs MG, Herbst RS, Walgren RA, Widau RC, Mi G, Jin J, Ferry D and Chau I: ramucirumab plus pembrolizumab in patients with previously treated advanced or metastatic biliary tract cancer: nonrandomized, open-label, phase I trial (JVDF). Oncologist 23(12): 1407-e136, 2018. PMID: 29853658. DOI: 10.1634/the oncologist.2018-0044

91 Sun W, Patel A, Normolle D, Patel K, Ohr J, Lee JJ, Bahary N, Chu E, Streeter $\mathrm{N}$ and Drummond S: A phase 2 trial of regorafenib as a single agent in patients with chemotherapy refractory advanced and metastatic biliary adenocarcinoma/ cholangiocarcinoma. J Clin Oncol 125(6): 902-909, 2019. PMID: 30561756. DOI: $10.1002 / \mathrm{cncr} .31872$

92 Kim RD, Poklepovic AS, Nixon AB, Kim DW, Soares HP, Kim J, Zhou JM, Tariq F, Burgess N and Sanoff HK: Multi institutional phase II trial of single agent regorafenib in refractory advanced biliary cancers. J Clin Oncol 36(15_suppl): 4082-4082, 2018. DOI: 10.1200/JCO.2018.36.15_suppl.4082

93 Bengala C, Bertolini F, Malavasi N, Boni C, Aitini E, Dealis C, Zironi S, Depenni R, Fontana A, Del Giovane C, Luppi G and Conte P: Sorafenib in patients with advanced biliary tract carcinoma: a phase II trial. Br J Cancer 102: 68-72, 2010. PMID: 19935794. DOI: $10.1038 /$ sj.bjc.6605458

94 Rose AAN: Encorafenib and binimetinib for the treatment of BRAF V600E/K-mutated melanoma. Drugs Today (Barc) 55(4): 247-264, 2019. PMID: 31050693. DOI: 10.1358/dot.2019. 55.4.2958476

95 Schaider $\mathrm{H}$ and Sturm RA: The evolving universe of BRAF mutations in melanoma. Br J Dermatol 177(4): 893, 2017. PMID: 29052896. DOI: $10.1111 /$ bjd.15829

96 Iyer P, Chen MH, Goyal L and Denlinger CS: Targets for therapy in biliary tract cancers: the new horizon of personalized medicine. Chin Clin Oncol 9(1): 7, 2020. PMID: 32146818. DOI: 10.21037/cco.2019.12.11

97 Hyman DM, Puzanov I, Subbiah V, Faris JE, Chau I, Blay JY, Wolf J, Raje NS, Diamond EL, Hollebecque A, Gervais R, ElezFernandez ME, Italiano A, Hofheinz RD, Hidalgo M, Chan E, Schuler M, Lasserre SF, Makrutzki M, Sirzen F, Veronese ML, Tabernero J and Baselga J: Vemurafenib in multiple nonmelanoma cancers with BRAF V600 mutations. N Engl J Med 373: 726-736, 2015. PMID: 26287849. DOI: 10.1056/NEJMoa1502309

98 Bekaii-Saab T, Phelps MA, Li X, Saji M, Goff L, Kauh JS, O’Neil BH, Balsom S, Balint C, Liersemann R, Vasko VV, Bloomston M, Marsh W, Doyle LA, Ellison G, Grever M, Ringel MD and Villalona-Calero MA: Multi-institutional phase II study of selumetinib in patients with metastatic biliary cancers. J Clin Oncol 29: 2357-2363, 2011. PMID: 21519026. DOI: 10.1200/ JCO.2010.33.9473

99 Kim RD, McDonough SL, El-Khoueiry AB, Bekaii-Saab TS, Stein S, Sahai V, Keogh GP, Kim EJ, Baron AD, Siegel AB, Barzi A, Guthrie K, Javle MM and Hochster HS: SWOG S1310: Randomized phase II trial of single agent MEK inhibitor trametinib vs. 5-fluorouracil or capecitabine in refractory advanced biliary cancer. J Clin Oncol 35(15_suppl): 4016, 2017. DOI: 10.1200/JCO.2017.35.15_suppl.4016

100 Finn RS, Ahn DH, Javle MM, Tan BR Jr, Weekes CD, Bendell JC, Patnaik A, Khan GN, Laheru D, Chavira R, Christy-Bittel J, Barrett E, Sawyer MB and Bekaii-Saab TS: Phase 1b investigation of the MEK inhibitor binimetinib in patients with advanced or metastatic biliary tract cancer. Invest New Drugs 36 : 1037-1043, 2018. PMID: 29785570. DOI: 10.1007/s10637-0180600-2

$101 \mathrm{Kim}$ JW, Lee KH, Kim JW, Nam AR, Bang JH, Bang YJ and Oh DJ: Enhanced antitumor effect of binimetinib in combination with capecitabine for biliary tract cancer patients with mutations in the RAS/RAF/MEK/ERK pathway: phase Ib study. Br J Cancer 121: 332-339, 2019. PMID: 31312030. DOI: 10.1038/s41416-019$0523-5$

102 Wainberg ZA, Lassen UN, Elez E, Italiano A, Curigliano G, De Braud FG, Prager G, Greil R, Stein A, Fasolo A, Schellens JHM, Wen PY, Boran AD, Burgess P, Gasal E, Ilankumaran P and Subbiah V: Efficacy and safety of dabrafenib (D) and trametinib $(\mathrm{T})$ in patients (pts) with BRAF V600E-mutated biliary tract cancer (BTC): A cohort of the ROAR basket trial. J Clin Oncol 37: 187, 2019. DOI: 10.1200/JCO.2019. 37.4_suppl.187

103 Di Nunno V, Massari F, Mollica V, Cimadamore A, Santoni M, Cheng L, Lopez-Beltran A, Scarpelli M and Montironi R: Another one in the chamber: cabozantinib for patients with metastatic non clear cell renal cell carcinoma. Ann Transl Med 7: S137, 2019. PMID: 31576344. DOI: 10.21037/atm.2019.06.06 
104 Zhang J, Jiang X, Jiang Y, Guo M, Zhang S, Li J, He J, Liu J, Wang $J$ and Ouyang L: Recent advances in the development of dual VEGFR and c-Met small molecule inhibitors as anticancer drugs. Eur J Med Chem 108: 495-504, 2016. PMID: 26717201. DOI: $10.1016 /$ j.ejmech.2015.12.016

105 Appleman LJ: MET signaling pathway: a rational target for cancer therapy. J Clin Oncol 29(36): 4837-4838, 2011. PMID: 22042966. DOI: 10.1200/JCO.2011.37.7929

106 Miyamoto, M. Ojima H, Iwasaki M, Shimizu H, Kokubu A, Hiraoka N, Kosuge T, Yoshikawa D, Kono T, Furukawa H and Shibata T: Prognostic significance of overexpression of c-Met onco- protein in cholangiocarcinoma. Br J Cancer 105: 131-138, 2011. PMID: 21673683. DOI: 10.1038/bjc.2011.199

$107 \mathrm{Pu}$ XH, Yue S, Wu HY, Yang J, Fan XS, Fu Y, Ye Q and Chen J: $\mathrm{C}$-MET in intrahepatic cholangiocarcinoma: High-Frequency amplification predicts protein expression and a unique molecular subtype. Pathol Res Pract 216(4): 152857, 2020. PMID: 32089411. DOI: 10.1016/j.prp.2020.152857

108 Yakes FM, Chen J, Tan J, Yamaguchi K, Shi Y, Yu P, Qian F, Chu F, Bentzien F, Cancilla B, Orf J, You A, Laird AD, Engst S, Lee L, Lesch J, Chou YC and Joly AH: Cabozantinib (XL184), a novel MET and VEGFR2 inhibitor, simultaneously suppresses metastasis, angiogenesis, and tumor growth. Mol. Cancer Ther 10: 2298-2308, 2011. PMID: 21926191. DOI: 10.1158/1535-7163.MCT-11-0264

109 Goyal L, Zheng H, Yrgelun MB, Abrams TA, Allen JN, Cleary JM, Knowles M, Regan E, Reardon A, Khachatryan A, Jain RK, Nardi V, Borger DR, Duda DG and Zhu AX: A phase 2 and biomarker study of cabozantinib in patients with advanced cholangiocarcinoma. Cancer 123(11): 1979-1988, 2017. PMID: 28192597. DOI: $10.1002 /$ cncr.30571

110 Zuo M, Rashid A, Churi C, Vauthey JN, Chang P, Li Y, Hung MC, Li D and Javle M: Novel therapeutic strategy targeting the Hedgehog signalling and mTOR pathways in biliary tract cancer. Br J Cancer 112(6): 1042-1051, 2015. PMID: 25742482. DOI: 10.1038/bjc.2014.625

111 Corti F, Nichetti F, Raimondi A, Niger M, Prinzi N, Torchio M, Tamborini E, Perrone F, Pruneri G, Di Bartolomeo M, de Braud $\mathrm{F}$ and Pusceddu S: Targeting the PI3K/AKT/mTOR pathway in biliary tract cancers: A review of current evidences and future perspectives. Cancer Treat Rev 72: 45-55, 2019. PMID: 30476750. DOI: 10.1016/j.ctrv.2018.11.001

112 Turkes F, Carmichael J, Cunningham D and Starling N: Contemporary tailored oncology treatment of biliary tract cancers. Gastroenterol Res Pract 2019: 7698786, 2019. PMID: 31929787. DOI: $10.1155 / 2019 / 7698786$

113 Massari F, Di Nunno V, Mollica V, Graham J, Gatto L and Heng D: Adjuvant tyrosine kinase inhibitors in treatment of renal cell carcinoma: a meta-analysis of available clinical trials. Clin Genitourin Cancer 17(2): e339-e344, 2019. PMID: 30704796. DOI: $10.1016 /$ j.clgc.2018.12.011

114 Wilson JM, Kunnimalaiyaan S, Kunnimalaiyaan M and Gamblin TC: Inhibition of the AKT pathway in cholangiocarcinoma by MK2206 reduces cellular viability via induction of apoptosis. Cancer Cell Int 15: 13, 2015. PMID: 25674039. DOI: 10.1186/s12 935-015-0161-9

115 Liu DC and Yang ZL: Overexpression of EZH2 and loss of expression of PTEN is associated with invasion, metastasis, and poor progression of gallbladder adenocarcinoma. Pathol Res Pract 207(8): 472-478, 2011. PMID: 21719208. DOI: 10.1016/ j.prp.2011.05.010
116 Dormond O: mTOR in human diseases. Int J Mol Sci 20(9), 2019. PMID: 31083592. DOI: 10.3390/ijms20092351

117 Ahn DH, Li J, Wei L, Doyle A, Marshall JL, Schaaf LJ, Phelps MA, Villalona-Calero MA and Bekaii-Saab T: Results of an abbreviated phase-II study with the Akt inhibitor MK-2206 in patients with advanced biliary cancer. Sci Rep 5: 12122, 2015. PMID: 26161813. DOI: 10.1038/srep12122

118 Buzzoni R, Pusceddu S, Bajetta E, De Braud F, Platania M, Iannacone C, Cantore M, Mambrini A, Bertolini A, Alabiso O, Ciarlo A, Turco C and Mazzaferro V: Activity and safety of RAD001 (everolimus) in patients affected by biliary tract cancer progressing after prior chemotherapy: a phase II ITMO study. Ann Oncol 25(8): 1597-1603, 2014. DOI: 10.1093/annonc/mdu175

119 Sakamoto Y, Yamagishi S, Tanizawa Y, Tajimi M, Okusaka T and Ojima H: PI3K-mTOR pathway identified as a potential therapeutic target in biliary tract cancer using a newly established patient-derived cell panel assay Jpn J Clin Oncol 48: 396-399, 2018. PMID: 29474549. DOI: 10.1093/jjco/hyy011

$120 \mathrm{Wu}$ CE, Chen MH and Yeh CN: mTOR inhibitors in advanced biliary tract cancers. Int J Mol Sci 20(3), 2019. PMID: 30682771. DOI: $10.3390 /$ ijms 20030500

121 Ricci AD, Rizzo A, Novelli M, Tavolari S, Palloni A, Tober N, Abbati F, Mollica V, DE Lorenzo S, Turchetti D, DI Marco M and Brandi G: Specific toxicity of maintenance olaparib versus placebo in advanced malignancies: A systematic review and metaanalysis. Anticancer Res 40(2): 597-608, 2020. PMID: 32014900. DOI: 10.21873/anticanres.13989

122 Heeke AL, Pishvaian MJ, Lynce F, Xiu J, Brody JR, Chen WJ, Baker TM, Marshall JL and Isaacs C: Prevalence of homologous recombination-related gene mutations across multiple cancer types. JCO Precis Oncol (2): 1-13, 2018. PMID: 30234181. DOI: 10.1200/PO.17.00286

123 Chae H, Kim D, Yoo C, Kim KP, Jeong JH, Chang HM, Lee SS, Park DH, Song TJ, Hwang S, Kim KH, Song GW, Ahn CS, Lee JH, Hwang DW, Kim SC, Jang SJ, Hong SM, Kim TW and Ryoo BY: Therapeutic relevance of targeted sequencing in management of patients with advanced biliary tract cancer: DNA damage repair gene mutations as a predictive biomarker. Eur J Cancer 120: 3139, 2019. PMID: 31476489. DOI: 10.1016/j.ejca.2019.07.022

124 Jain A, Kwong LN and Javle M: Genomic profiling of biliary tract cancers and implications for clinical practice. Curr Treat Options Oncol 17(11), 2016. PMID: 27658789. DOI: 10.1007/ s11864-016-0432-2

125 Golan T, Raitses-Gurevich M, Kelley RK, Bocobo AG, Borgida A, Shroff RT, Holter S, Gallinger S, Ahn DH, Aderka D, Apurva J, Bekaii-Saab T, Friedman E and Javle M: Overall survival and clinical characteristics of BRCA-associated cholangiocarcinoma: A multicenter retrospective study. Oncologist 22(7): 804-810, 2017. PMID: 28487467. DOI: 10.1634/theoncologist.2016-0415

126 Ahn DH and Bekaii-Saab T: Biliary tract cancer and genomic alterations in homologous recombinant deficiency: Exploiting synthetic lethality with PARP inhibitors. Chinese Clin Oncol 9(1): 1-6, 2020. PMID: 32075397. DOI: 10.21037/cco.2020.02.02

127 Loeuillard E, Conboy CB, Gores GJ and Rizvi S: Immunobiology of cholangiocarcinoma. JHEP Rep 1(4): 297-311, 2019. PMID: 32039381. DOI: 10.1016/j.jhepr.2019.06.003

128 Sartore-Bianchi A, Pizzutilo EG, Marrapese G, Tosi F, Cerea G and Siena S: Entrectinib for the treatment of metastatic NSCLC: safety and efficacy. Expert Rev Anticancer Ther 8: 1-9, 2020. PMID: 32223357. DOI: 10.1080/14737140.2020.1747439 
129 Kheder ES and Hong DS: Emerging targeted therapy for tumors with NTRK fusion proteins. Clin Cancer Res 24(23): 5807-5814, 2018. PMID: 29986850. DOI: 10.1158/1078-0432.CCR-18-1156.

130 Lavacchi D, Roviello G and D'Angelo A: Tumor-agnostic treatment for cancer: When how is better than where. Clin Drug Investig, 2020. PMID: 32307639. DOI: 10.1007/s40261-02000915-5

131 Amatu A, Sartore-Bianchi A and Siena S: NTRK gene fusions as novel targets of cancer therapy across multiple tumour types. ESMO Open 1(2): e000023, 2016. PMID: 27843590. DOI: 10.1136/esmoopen-2015-000023

132 Drilon A, Laetsch TW, Kummar S, DuBois SG, Lassen UN, Demetri GD, Nathenson M, Doebele RC, Farago AF, Pappo AS, Turpin B, Dowlati A, Brose MS, Mascarenhas L, Federman N, Berlin J, El-Deiry WS, Baik C, Deeken J, Boni V, Nagasubramanian R, Taylor M, Rudzinski ER, Meric-Bernstam F, Sohal DPS, Ma PC, Raez LE, Hechtman JF, Benayed R, Ladanyi M, Tuch BB, Ebata K, Cruickshank S, Ku NC, Cox MC, Hawkins DS, Hong DS and Hyman DM: Efficacy of larotrectinib in TRK fusion-positive cancers in adults and children. N Engl J Med 378(8): 731-739, 2018. PMID: 29466156. DOI: 10.1056/NEJMoa1714448

133 Scott LJ: Larotrectinib: First global approval. Drugs 79(2): 201206, 2019. PMID: 30635837. DOI: 10.1007/s40265-018-1044-x

134 Doebele RC, Drilon A, Paz-Ares L, Siena S, Shaw AT, Farago AF, Blakely CM, Seto T, Cho BC, Tosi D, Besse B, Chawla SP, Bazhenova L, Krauss JC, Chae YK, Barve M, Garrido-Laguna I, Liu SV, Conkling P, John T, Fakih M, Sigal D, Loong HH, Buchschacher GL Jr, Garrido P, Nieva J, Steuer C, Overbeck TR, Bowles DW, Fox E, Riehl T, Chow-Maneval E, Simmons B, Cui $\mathrm{N}$, Johnson A, Eng S, Wilson TR and Demetri GD; trial investigators: Entrectinib in patients with advanced or metastatic NTRK fusion-positive solid tumours: integrated analysis of three phase 1-2 trials. Lancet Oncol 21(2): 271-282, 2020. PMID: 31838007. DOI: 10.1016/S1470-2045(19)30691-6.

135 Solomon JP and Hechtman JF: Detection of NTRK fusions: Merits and limitations of current diagnostic platforms. Cancer Res 79(13): 3163-3168. PMID: 3119631. DOI: 10.1158/0008-5472

136 Gambella A, Senetta R, Collemi G, Vallero SG, Monticelli M, Cofano F, Zeppa P, Garbossa D, Pellerino A, Rudà R, Soffietti R, Fagioli F, Papotti M, Cassoni P and Bertero L: NTRK fusions in central nervous system tumors: a rare, but worthy target. Int J Mol Sci 21(3), 2020. PMID: 31979374. DOI: 10.3390/ijms 21030753

137 Farago AF and Demetri GD: Larotrectinib, a selective tropomyosin receptor kinase inhibitor for adult and pediatric tropomyosin receptor kinase fusion cancers. Future Oncol 16(9): 417-425, 2020. PMID: 32129093. DOI: 10.2217/fon-2019-0647

138 Rizzo A, Pantaleo MA, Saponara M and Nannini M: Current status of the adjuvant therapy in uterine sarcoma: A literature review. World J Clin Cases 7(14): 1753-1763, 2019. PMID: 31417921. DOI: 10.12998/wjcc.v7.i14.1753

139 Massari F, Nunno VD, Mollica V, Montironi R, Cheng L, Cimadamore A, Blanca A and Lopez-Beltran A: Immunotherapy in renal cell carcinoma from poverty to the spoiled of choice. Immunotherapy 11(17): 1507-1521, 2019. PMID: 31663411. DOI: 10.2217/imt-2019-0115

140 Chen $\mathrm{H}$, Chong W, Wu Q, Yao Y, Mao M and Wang X: Association of LRP1B mutation with tumor mutation burden and outcomes in melanoma and non-small cell lung cancer patients treated with immune check-point blockades. Front Immunol 10: 1113, 2019. PMID: 31164891. DOI: 10.3389/fimmu .2019.01113

141 Singal G, Miller PG, Agarwala V, Li G, Kaushik G, Backenroth D, Gossai A, Frampton GM, Torres AZ, Lehnert EM, Bourque D, O'Connell C, Bowser B, Caron T, Baydur E, Seidl-Rathkopf K, Ivanov I, Alpha-Cobb G, Guria A, He J, Frank S, Nunnally AC, Bailey M, Jaskiw A, Feuchtbaum D, Nussbaum N, Abernethy AP and Miller VA: Association of patient characteristics and tumor genomics with clinical outcomes among patients with non-small cell lung cancer using a clinicogenomic database. JAMA 321(14): 1391-1399, 2019. PMID: 30964529. DOI: 10.1001/jama.2019.3241

142 Gubin MM, Zhang X, Schuster H, Caron E, Ward JP, Noguchi T, Ivanova Y, Hundal J, Arthur CD, Krebber WJ, Mulder GE, Toebes M, Vesely MD, Lam SS, Korman AJ, Allison JP, Freeman GJ, Sharpe AH, Pearce EL, Schumacher TN, Aebersold R, Rammensee HG, Melief CJ, Mardis ER, Gillanders WE, Artyomov MN and Schreiber RD: Checkpoint blockade cancer immunotherapy targets tumour-specific mutant antigens. Nature 515: 577-581, 2014. PMID: 25428507. DOI: 10.1038/nature13988

143 Zhao P, Li L, Jiang $\mathrm{X}$ and $\mathrm{Li} \mathrm{Q}$ : Mismatch repair deficiency/microsatellite instability-high as a predictor for antiPD-1/PD-L1 immunotherapy efficacy. J Hematol Oncol 12(1): 54, 2019. PMID: 31151482. DOI: 10.1186/s13045-019-0738-1

144 Lemery S, Keegan P and Pazdur R: First FDA approval agnostic of cancer site - when a biomarker defines the indication. N Engl J Med 377(15): 1409-1412, 2017. PMID: 29020592. DOI: 10.1056/NEJMp1709968

145 Mertens JC, Rizvi S and Gores GJ: Targeting cholangiocarcinoma. Biochim Biophys Acta Mol Basis Dis 1864(4 Pt B): 1454-1460, 2018. PMID: 28844952. DOI: 10.1016/j.bbadis.2017. 08.027

146 Bang YJ, Doi T, De Braud F, Piha-Paul S, Hollebecque A, Abdul Razak AR, Lin CC, Ott PA, He AR, Yuan SS, Koshiji M, Lam B and Aggarwal R: 525 Safety and efficacy of pembrolizumab (MK-3475) in patients (pts) with advanced biliary tract cancer: interim results of KEYNOTE-028. Eur J Cancer 51: S112, 2015. DOI: 10.1016/S0959-8049(16)30326-4

147 Bang YJU, Ueno M, Malka D, Chung HC, Nagrial A, Kelley RK, Piha-Paul SA, Ros W, Italiano A, Nakagawa K, Rugo HS, De Braud F, Varga AI, Hansen AR, Gao C, Krishnan S, Norwood K and Doi T: Pembrolizumab (pembro) for advanced biliary adenocarcinoma: Results from the KEYNOTE-028 (KN028) and KEYNOTE-158 (KN158) basket studies. Am Soc Clin Oncol Annual Meeting; 2019; Chicago, IL, USA. J Clin Oncol 37(15_suppl): 4079, 2019. DOI: 10.1200/JCO.2019.37.15_ suppl.4079

148 Kim RD, Chung V, Alese OB, El-Rayes BF, Li D, Al-Toubah TE, Schell MJ, Zhou JM, Mahipal A, Kim BH and Kim DW: A phase 2 multi-institutional study of nivolumab for patients with advanced refractory biliary tract cancer. JAMA Oncol, 2020. PMID: 32352498. DOI: 10.1001/jamaoncol.2020.0930

149 Ioka T, Ueno M, Oh DY, Fujiwara Y, Chen JS, Doki Y, Mizuno N, Park K, Asagi A, Hayama M, Nii M, Komuro K, Suginmoto $M$, Vlahovic G and Ikeda M: Evaluation of safety and tolerability of durvalumab (D) with or without tremelimumab (T) in patients (pts) with biliary tract cancer (BTC). JCO 37: 387, 2019. DOI: 10.1200/JCO.2019.37.4_suppl.387

150 Arkenau HT, Martin-Liberal J, Calvo E, Penel N, Krebs MG, Herbst RS, Walgren RA, Widau RC, Mi G, Jin J, Ferry D and Chau I: Ramucirumab plus pembrolizumab in patients with 
previously treated advanced or metastatic biliary tract cancer: nonrandomized, open-label, phase I trial (JVDF). Oncologist 23: 1407-e136, 2018. PMID: 29853658. DOI: 10.1634/ theoncologist.2018-0044

151 Lin J, Shi W, Zhao S, Hu J, Hou Z, Yao M, Chrin G, Pan J, Hu $\mathrm{K}$, Zhao L, Javle $\mathrm{M}$, Wang $\mathrm{K}$ and Zhao $\mathrm{H}$ : Lenvatinib plus checkpoint inhibitors in patients (pts) with advanced intrahepatic cholangiocarcinoma (ICC): Preliminary data and correlation with next-generation sequencing. JCO 36: 500, 2018. DOI: 10.1200/JCO.2018.36.4_suppl.500

152 Neuzillet C, Casadei Gardini A, Brieau B, Vivaldi C, Smolenschi C, Brandi G, Tougeron D, Filippi R, Vienot A, Silvestris N, Pointet AL, Lonardi S, Rousseau B, Scartozzi M, Dahan L, Aprile G, Boussaha T, Malka D, Crusz SM, Le Sourd S, Meurisse A, Lièvre A, Vernerey D; AGEO (Association des Gastro-Entérologues Oncologues); GICO (Italian Group of Cholangiocarcinoma)
Investigators; Gustave Roussy Institute Cohort; Barts Cancer Institute Cohort: Prediction of survival with second-line therapy in biliary tract cancer: Actualisation of the AGEO CT2BIL cohort and European multicentre validations. Eur J Cancer 111: 94-106, 2019. PMID: 30826661. DOI: 10.1016/j.ejca.2019.01.019

153 Brandi G, Venturi M, Pantaleo MA and Ercolani G; GICO: Cholangiocarcinoma: Current opinion on clinical practice diagnostic and therapeutic algorithms: A review of the literature and a long-standing experience of a referral center. Dig Liver Dis 48(3): 231-241, 2016. PMID: 26769568. DOI: 10.1016/ j.dld.2015.11.017
Received May 1, 2020

Revised May 15, 2020

Accepted May 16, 2020 